\title{
Cell adhesion factors during adolescence support amygdalo-cortical connections and flexible action later in life
}

\author{
Henry W. Kietzman ${ }^{1-4}$, Lauren P. Shapiro ${ }^{2,4,5}$, Gracy Trinoskey-Rice ${ }^{2,4}$, Jidong Guo ${ }^{4}$, Shannon L. \\ Gourley $^{2-6}$ \\ ${ }^{1}$ Medical Scientist Training Program, Emory University School of Medicine \\ ${ }^{2}$ Departments of Pediatrics and Psychiatry, Emory University School of Medicine \\ ${ }^{3}$ Graduate Program in Neuroscience, Emory University \\ ${ }^{4}$ Yerkes National Primate Research Center, Emory University \\ ${ }^{5}$ Graduate Program in Molecular and Systems Pharmacology, Emory University \\ ${ }^{6}$ Children's Healthcare of Atlanta \\ Contact: \\ Shannon L. Gourley \\ Yerkes National Primate Research Center \\ Emory University \\ 954 Gatewood Rd. NE \\ Atlanta GA 30329 \\ Email: shannon.l.gourley@emory.edu \\ 404-727-2482
}

Author Contributions: H.W.K., L.P.S., and S.L.G. designed research; H.W.K., L.P.S., G.T-R. and J.G. performed research; H.W.K., L.P.S., G.T-R., J.G., and S.L.G. analyzed data; H.W.K and S.L.G. wrote the paper; H.W.K., L.P.S., G.T-R., J.G., and S.L.G. edited the paper.

Competing Interest Statement: The authors do not declare any competing interests.

Keywords: CD29, habit, Itgb1, juvenile, mPFC 


\section{Abstract}

1 Adolescent brain development is characterized by dramatic neuronal remodeling in the prefrontal

2 cortex. This plasticity is presumed to act in part to "set the stage" for prefrontal cortical function in

3 adulthood, but causal relationships have largely not been verified. Integrins are cell adhesion

4 factors that provide a link between the extracellular matrix and the intracellular actin cytoskeleton.

5 We find that $\beta 1$-integrin presence in the prelimbic subregion of the prefrontal cortex $(P L)$ during

6 adolescence, but not adulthood, is necessary for adult mice to select actions based on reward

7 likelihood and value. These behaviors require coordinated limbic-frontal-striatal circuits. We

8 identified projections from the basolateral amygdala (BLA) to PL as being necessary for mice to

9 express learned response strategies. We then visualized adolescent PL neurons receiving input

10 from the BLA and projecting to the dorsomedial striatum (DMS), a primary striatal output by which

11 the PL controls reward-related behavior. These projection-defined neurons had a more "adult-like"

12 morphology relative to a general population of layer V PL neurons. $\beta 1$-integrin loss caused the

13 overexpression of stubby-type dendritic spines at the expense of more mature spines, a phenotype

14 not observed when $\beta 1$-integrins were silenced before or after adolescence. Together, these

15 experiments localize $\beta 1$-integrin-mediated cell adhesion activity within a developing di-synaptic

16 circuit that coordinates flexible action. 


\section{Introduction}

Neurodevelopment during adolescence is characterized by dramatic structural plasticity within the prefrontal cortex (PFC), involving both the elimination of dendritic spines and the stabilization of other spines ${ }^{1,2}$. Early-life development is the subject of intense investigation, but mechanisms underlying adolescent brain development are still unclear - even despite $\sim 50 \%$ of "adult" mental health disorders initially presenting during adolescence ${ }^{3}$. Further, structural irregularities in the PFC are linked to the cognitive symptomatology of nearly every major neurodevelopmental disorder ${ }^{4-6}$. Thus, investigating factors that govern structural stability referring here to the process by which dendritic spines are retained and escape pruning - is a crucial step in understanding neurodevelopment during adolescence and potentially, disease etiologies.

Integrins are heterodimeric transmembrane cell adhesion receptors that provide a link between the extracellular matrix (ECM) and the intracellular actin cytoskeleton. Integrins, composed of a ligand-binding $\alpha$ subunit and a $\beta$ subunit that activates intracellular signaling cascades, respond to ECMs, either to maintain structural integrity and functionality, or to promote tissue differentiation and development ${ }^{7}$. In early life, $\beta 1$-subunit-containing integrin receptors promote neurite outgrowth ${ }^{8}$ and axon guidance ${ }^{9}$. Investigations focused on hippocampal CA1 suggest that during adolescence, $\beta 1$-integrins may fulfill a distinct function: stabilizing dendrites and synapses ${ }^{10}$, thereby supporting long-term potentiation ${ }^{11}$. Levels of the neuronal $\beta 1$-integrin signaling partners, p190RhoGAP and Rho-kinase 2 (ROCK2), peak in the PFC during adolescence, suggesting that $\beta 1$-integrin-mediated signaling in adolescence might stabilize PFC neuron structure and function ${ }^{12}$.

Broadly, the PFC, and the prelimbic subregion (PL) in particular, controls the ability of organisms to link actions with their likely outcomes and to flexibly modify behaviors when contingencies change ${ }^{13,14}$. Here, we report that $\beta 1$-integrin presence in the PL during adolescence, but not later, is necessary for flexible reward-related behavior in adulthood. As such, mice deficient in developmental $\beta 1$-integrins struggle to: 1) associate actions with outcomes and 2) select actions based on outcome value. These behaviors require coordinated limbic-frontal-striatal circuits ${ }^{14}$. We 
45 identified projections from the basolateral amygdala (BLA) to PL as being necessary for mice to 46 express learned response strategies. This led us to characterize the dendritic micro-architecture of

47 adolescent layer V PL neurons receiving input from the BLA and projecting to the dorsomedial 48 striatum (DMS), a primary striatal output necessary for goal-oriented action ${ }^{15}$. Surprisingly, these 49 projection-defined neurons had a more "adult-like" morphology relative to a general population of 50 layer V PL neurons. $\beta 1$-integrin loss caused the overexpression of stubby-type dendritic spines, 51 which are unlikely to contain synapses, at the expense of mature spine types. Together, these 52 experiments indicate that $\beta 1$-integrin presence during adolescence structurally stabilizes PL 53 neurons positioned within a di-synaptic circuit, providing the structural substrates for flexible action 54 later in life. 


\section{Results}

\section{Cell adhesion during adolescence optimizes flexible action in adulthood}

57 We aimed to understand the function of $\beta 1$-integrins in the developing postnatal PFC. To

58 reduce $\beta 1$-integrins, we introduced a CaMKIl $\alpha$-driven adeno-associated viral vector (AAV)

59 expressing Cre recombinase (Cre) into the PL of transgenic Itbg1tm1Efu (Itgb1-flox) mice. These

60 mice have loxP sites flanking exon 3 of $\lg 1$ 1, the gene that encodes $\beta 1$-integrins; Cre introduction

61 deletes this exon ${ }^{16}$. Cre was delivered early in life, to reduce $\beta 1$-integrins starting in adolescence,

62 or for comparison, in adulthood (infusions at P21-24 or $\geq P 56-60$, respectively; ages and viral vector

63 details for all experiments are described in table 1). Fig.1a depicts viral vector spread, comparable

64 across ages; any mice with unilateral or off-target transfection were excluded.

65 Table 1. Genotype, age, and viral vector details for all experiments. Infusions were in 66 the PL unless otherwise indicated in parentheses.

\begin{tabular}{|c|c|c|c|c|}
\hline Fig. & $\begin{array}{l}\text { Geno } \\
\text { type } \\
\text { of } \\
\text { mice }\end{array}$ & $\begin{array}{l}\text { Timing } \\
\text { of viral } \\
\text { vector } \\
\text { delivery }\end{array}$ & Viral vector conditions & Measure \\
\hline $\begin{array}{l}1 \mathrm{a} \\
2\end{array}$ & $\begin{array}{l}\text { Itgb1- } \\
\text { flox }\end{array}$ & $\begin{array}{l}\text { P21-24 } \\
\text { vs. } \\
>\text { P } 56\end{array}$ & $\begin{array}{l}\text { Knockdown: AAV2/8-CaMKIl } \alpha-m \text { Cherry+Cre } \\
\text { Control: AAV2/8-CaMKIl } \alpha \text {-mCherry }\end{array}$ & $\begin{array}{l}\text { Behavioral } \\
\text { testing }\end{array}$ \\
\hline $\begin{array}{l}\text { 1b- } \\
c\end{array}$ & $\begin{array}{l}\text { Itgb1- } \\
\text { flox }\end{array}$ & P21-24 & $\begin{array}{l}\text { Knockdown: AAV2/8-CaMKIl } \alpha \text {-mCherry+Cre } \\
\text { Control: AAV2/8-CaMKIll } \alpha \text {-mCherry }\end{array}$ & $\begin{array}{l}\text { Immuno- } \\
\text { blotting for } \\
\beta 1 \text {-integrins }\end{array}$ \\
\hline 3 & $\begin{array}{l}\text { wild } \\
\text { type }\end{array}$ & $\geq P 56$ & $\begin{array}{l}\text { All mice: rgAAV(pENN)-hSyn-HI-eGFP-Cre-WPRE (PL) } \\
\text { AAV5-hSyn-DIO-mCherry+hM4Di (BLA); } \\
\text { comparisons were media } \pm C N O \text { or cells } \pm \text { hM4Di }\end{array}$ & $\begin{array}{l}\text { Electro- } \\
\text { physiology }\end{array}$ \\
\hline 4 & $\begin{array}{l}\text { wild } \\
\text { type }\end{array}$ & $\geq$ P56 & $\begin{array}{l}\text { Projection-specific inactivation: rgAAV(pENN)-hSyn-HI-eGFP- } \\
\text { Cre-WPRE (PL) } \\
\text { AAV5-hSyn-DIO-mCherry+hM4Di (BLA) } \\
\text { Control: gAAV(pENN)-hSyn-HI-eGFP-Cre-WPRE (PL) } \\
\text { AAV5-hSyn-DIO-mCherry (BLA) }\end{array}$ & $\begin{array}{l}\text { Behavioral } \\
\text { testing }\end{array}$ \\
\hline $\begin{array}{l}5, \\
\text { S1 }\end{array}$ & $\begin{array}{l}\text { Itgb1- } \\
\text { flox/ } \\
\text { Thy1- } \\
\text { YFP }\end{array}$ & $\begin{array}{l}\text { P21-24 } \\
\text { vs. } \\
\geq P 56\end{array}$ & $\begin{array}{l}\text { Visualization of projection-defined PL neurons: rgAAV-hSyn-DIO- } \\
\text { mCherry (DMS) } \\
\text { AAV1-hSyn-Cre-WPRE-hGH (BLA) } \\
\text { Visualization of general layer V populations: AAV2/8-CaMKIll- } \\
\text { mCherry }\end{array}$ & $\begin{array}{l}\text { Dendritic } \\
\text { spine } \\
\text { analysis }\end{array}$ \\
\hline $\begin{array}{l}\text { 6, } \\
\text { S1, } \\
\text { S2 }\end{array}$ & $\begin{array}{l}\text { ltgb1- } \\
\text { flox/ } \\
\text { Thy1- } \\
\text { YFP }\end{array}$ & $\begin{array}{l}\mathrm{P} 21-24 \\
\text { vs. } \\
\geq \mathrm{P} 56\end{array}$ & $\begin{array}{l}\text { Adolescent Itgb1 knockdown in projection-defined neurons: } \\
\text { rgAAV-hSyn-DIO-mCherry (DMS) } \\
\text { AAV1-hSyn-Cre-WPRE-hGH (BLA) } \\
\text { Adolescent projection-defined control neurons: rgAAV-hSyn-DIO- } \\
\text { mCherry (DMS) } \\
\text { AAV1-hSyn-Cre-WPRE-hGH (BLA) (delivered to Itgb1-flox--- } \\
\text { littermates) } \\
\text { Adolescent- or adult-onset Itgb1 knockdown in general layer V } \\
\text { neurons: AAV2/8-CaMKIlo-mCherry+Cre } \\
\text { Adolescent- or adult-onset general layer V control neurons: } \\
\text { AAV2/8-CaMKIl } \alpha \text {-mCherry }\end{array}$ & $\begin{array}{l}\text { Dendritic } \\
\text { spine } \\
\text { analysis }\end{array}$ \\
\hline
\end{tabular}


68 tissue punches by $21 \%\left[t_{(9)}=3.30, p=0.009\right]$ (fig. $1 \mathrm{~b}$ ), comparable to effects of the same gene

69 silencing approach in mature mice ${ }^{17}$. Note that incomplete protein loss was expected, given that

70 tissue punches processed by western blot contained both transduced and unaffected tissues, and

71 CaMKIl $\alpha$-driven AAVs would be expected to spare glial $\beta 1$-integrins, which are expressed at high

72 levels ${ }^{18}$. (Western blot was used because immunostaining brain tissue with currently-available

73 antibodies is quite difficult.) Figures depict group means and individual mice throughout.

$74 \quad$ Neuronal $\beta 1$-integrin activation results in the phosphorylation of p190RhoGAP ${ }^{19}$. $\beta 1$ -

75 integrin protein levels correlated with the proportion of phospho-p190RhoGAP/p190RhoGAP in

76 knockdown mice, such that mice with fewer $\beta 1$-integrins also had the less phospho-p190RhoGAP

$77 \quad\left[r^{2}=0.490, p=0.036\right]$ (fig.1c), evidence that our gene silencing approach had functional

78 consequences for integrin-mediated intracellular signaling.

The PL is necessary for mice and rats to use associations between actions and outcomes

80 to guide choice behavior ${ }^{13}$. To understand whether $\beta 1$-integrins in adolescence are necessary for

81 this function in adulthood (i.e., to determine whether $\beta 1$-integrins equip developing mice with the

82 capacity for flexible choice behavior in adulthood), we reduced $\beta 1$-integrins in adolescence and

83 tested reward-related response strategies in adulthood. For comparison, we also reduced $\beta 1$ -

84 integrin presence in adulthood. Mice were trained to nose poke at 2 apertures for 2 distinct food

85 pellets (fig.2a). Groups did not differ in response acquisition, with mice increasing responding over

86 time [main effect of day $\left(F_{(6,312)}=33.26, p<0.0001\right)$, no day ${ }^{*}$ group interaction $\left(F_{(18,312)}=1.037\right.$,

$87 p=0.4180)$, no other main effects $(F s<1)]($ fig. $2 b)$. Further, there were no systematic preferences

88 for either flavor of pellet that would affect subsequent phases of testing $\left[F_{s}<1\right.$; not shown], so

89 response rates for both pellets are collapsed for simplicity.

90 Next, the contingency between 1 familiar action and its outcome was violated by providing

91 pellets non-contingently, or "for free." In reaction, control mice inhibited that response during a

92 probe test, preferring instead the response associated with the intact contingency. Meanwhile, loss

93 of $\beta 1$-integrins starting in adolescence, but not adulthood, ablated this preference [viral vector*age 
94 of knockdown*aperture interaction $\left(F_{(1,48)}=5.675, p=0.021\right)$, no other interactions $\left(F_{s}<1\right)$, main

95 effect of aperture $\left(F_{(1,48)}=47.09, p<0.001\right)$, no main effect of viral vector $(F<1)$ or age of knockdown

$\left.96\left(F_{(1,48)}=2.12, p=0.151\right)\right]($ fig.2c).

We also compared response preference scores, calculated by dividing responses associated with the intact/violated contingencies. A ratio of $>1$ reflects a preference for the intact contingency - i.e., flexible action - while scores of 1 indicate no preference. The response ratio was $\sim 1$ upon loss of $\beta 1$-integrins during adolescence, while other groups generated higher scores [viral vector*age of knockdown interaction $\left(F_{(1,46)}=6.484, p=0.014\right)$, main effect of viral vector

$102\left(F_{(1,46)}=4.629, p=0.037\right)$, no main effect of age of knockdown $\left.(F<1)\right]$ (fig.2d). Thus, developmental 103 integrins are necessary for the ability of mature mice to engage in flexible reward-related action.

105 is, knowledge that an action will lead to desired outcomes, as tested above - and selecting actions 106 based on the value of likely outcomes ${ }^{13}$. Thus, we hypothesized that developmental $\beta 1$-integrins 107 would also be necessary for mice to select actions based on outcome value, which we tested using 108 satiety-specific devaluation (fig.2e). Given that $\beta 1$-integrin loss in adulthood had no effects above, we focused on adolescent-onset $\beta 1$-integrin reduction. Following training, mice were allowed to

110 freely consume 1 of the 2 food reinforcers in a separate environment, decreasing the value of that 111 reinforcer. Groups did not differ in food consumption [ $\left.t_{(14)}=0.6750, p=0.5107\right]$ (fig.2f). Nevertheless,

112 only control mice preferentially responded for the other, "valued" food when returned to the operant 113 conditioning chambers, evidence that they selected actions based on outcome value. Meanwhile, 114 reducing $\beta 1$-integrins in adolescence blocked the ability of adult mice to select actions based on 115 outcome value [viral vector ${ }^{*}$ value interaction $\left(F_{(1,19)}=4.395, p=0.0497\right)$, no main effect of viral vector $116(F<1)$, no main effect of value $\left.\left(F_{(1,19)}=2.531, p=0.154\right)\right]$ (fig.2g). Accordingly, response ratios were 117 lower upon loss of $\beta 1$-integrins, reflecting no preference for the valued outcome [Welch's corrected $\left.118 t_{(15.40)}=2.660, p=0.0168\right]$ (fig.2h). Thus, developmental integrins are necessary for mature mice to 119 engage in goal-oriented action. 
121

122

123

124

125

\section{$B L A \rightarrow P L$ projections are necessary for the expression of learned reward-related action}

$\beta 1$-integrins are largely localized in the post-synapse of excitatory synapses in the postnatal brain, coordinating the stability of these synapses ${ }^{20,21}$. Thus, it seems likely that reducing Itgb1 during adolescent development disrupts the ability of mature PL neurons to effectively receive inputs necessary for goal-seeking behavior. We next attempted to identify sources of such inputs. One candidate region is the $B L A$, given that $B L A \rightarrow P L$ projections develop throughout adolescence 22 ; this development likely ensures that connections required for certain goal-seeking behaviors are accessible in adults ${ }^{23}, 24$. To determine whether these principles apply to the response strategies tested here, we first tested whether BLA $\rightarrow P L$ projections, independent of $\beta 1$ integrins, are indeed necessary for action selection based on reward likelihood. We used a combinatorial viral vector strategy, infusing a retro-Cre into the PL and Cre-dependent Gi-coupled Designer Receptors Exclusively Activated by Designer Drugs (Gi-DREADDs+mCherry) into the BLA (fig.3a). This combination would be expected to decrease the activity of BLA $\rightarrow$ PL projections in the presence of the DREADDs ligand, Clozapine $\mathrm{N}$-oxide (CNO). Mice in the control group were infused with the same viral vector in the PL and a control viral vector lacking DREADDs in the BLA.

To confirm the effectiveness of Gi-DREADDs, whole cell patch clamp recordings were obtained from BLA neurons (fig.3b). In Gi-DREADDs-mCherry(+), but not Gi-DREADDs-mCherry(), neurons, bath application of CNO $(10 \mu \mathrm{M})$ induced rapid and sustaining membrane hyperpolarization $\left[t_{(5)}=7.418, p=0.0007\right]$ (fig.3c,d). CNO also increased rheobase, or the minimum current required to generate a single action potential [paired $t_{(5)}=4.554, p=0.006$ ] (fig.3e,f). Lastly, we examined action potential firing induced by current injections. CNO reduced the number of spikes [main effect of CNO $\left(F_{(1,40)}=21.24, p<0.001\right)$, main effect of current $\left(F_{(6,40)}=9.049, p<0.001\right)$, no current ${ }^{\star} \mathrm{CNO}$ interaction $\left(F_{(6,40)}=0.277, p=0.944\right)$ ] (fig.3g,h). In summary, Gi-DREADDs decreased the excitability of PL-projecting BLA neurons when CNO was administered, as expected. Separate mice containing the same viral vectors (fig.4a,b) were trained and then behaviorally tested. In the task in which we tested behavioral sensitivity to contingency, the memory encoding and expression periods occur on separate days. This, in combination with the ability to inducibly silence neurons in a temporally-specific fashion using DREADDs (unlike with Itgb1 
149 silencing), allows us to disentangle whether BLA $\rightarrow$ PL projections are involved in memory encoding

150 or expression (fig.4c). CNO was delivered to all mice either before a session when a familiar

151 contingency was modified (during memory encoding), or ahead of the probe test (when mice must

152 express memories in making choices). Mice were tested in both conditions in a counter-balanced

153 fashion, and responses of control mice (mice bearing a control viral vector lacking DREADDs in

154 the BLA) were averaged across both testing conditions.

155 Groups did not differ in response acquisition [main effect of day $\left(F_{(6,108)}=17.36, p<0.0001\right)$,

156 no other main effects or interactions $(F s<1)$ ] (fig.4d). Silencing BLA $\rightarrow P L$ projections during the

157 probe test, but not earlier, ablated response preferences [group*aperture interaction $\left(F_{(2,24)}=3.424\right.$,

$158 p=0.042)$, main effect of aperture $\left(F_{(1,24)}=7.894, p=0.0097\right)$, no main effect of group $\left(F_{(2,24)}=2.884\right.$,

$159 p=0.0754)]$ (fig.4e). Accordingly, response ratios were lowest following BLA $\rightarrow P L$ inactivation during

160 the probe test $\left[F_{(2,24)}=5.904, p=0.008\right]$ (fig.4f). These patterns suggest that $B L A \rightarrow P L$ connections

161 are necessary for mice to express memories regarding reward likelihood and act accordingly, but

162 not to encode those memories per se.

Developmental $\beta 1$-integrins are necessary for the morphological features of PL neurons positioned within a BLA-PL-striatal circuit connections are necessary for action flexibility in adulthood. These observations led to the hypothesis that $\beta 1$-integrin presence sculpts the development of PL neurons receiving input from the BLA. Cortically-oriented BLA projections terminate on layer II, III, and V PL neurons ${ }^{25}$. We focus

170 here on layer $V$ neurons because these cells receive input from the BLA and send outputs to the 171 dorsomedial striatum (DMS), which is required for the translation of decision-making strategies into 172 action ${ }^{26,27}$.

173 It was first necessary to isolate and characterize PL neurons receiving inputs from the BLA 174 and projecting to the DMS under typical ( $\beta 1$-integrin+) conditions. We isolated projection-defined 175 PL neurons by infusing an anterograde transsynaptic Cre-expressing viral vector into the BLA and 176 a retrograde Cre-dependent mCherry-expressing viral vector into the DMS of adolescent Thy1- 
$177 \mathrm{YFP}^{\mathrm{H}}$ mice $^{28}$ (fig.5a-b). Thus, mCherry+, YFP+ co-labeled cells represent layer $\mathrm{V}$ neurons that 178 receive projections from the BLA, and project to the DMS (fig.5c). For comparison, we infused an 179 mCherry-expressing viral vector into the PL of adolescent and adult mice, allowing us to visualize 180 a general population of transduced layer $V$ neurons not defined by projection (fig.5d). As above, 181 viral vectors were infused at P21-24 or P56-60, and mice were euthanized 3 weeks later (fig.5e). 182 We then utilized high resolution imaging and 3D dendritic spine reconstruction to analyze the 183 dendritic micro-architecture of each population.

$184 \quad$ Interestingly, projection-defined PL neurons had lower dendritic spine densities than either 185 adult or adolescent undefined PL layer V populations (fig.S1). To account for these differences, we 186 focused here on the proportions of mature and immature spine subtypes, given that the balance 187 between mature vs. immature spine subtypes allows for the prioritization and integration of certain 188 inputs over others ${ }^{29}$. The proportion of immature, stubby-shaped dendritic spines was highest in 189 adulthood and lowest in adolescence, and projection-defined neurons had an intermediate 190 phenotype, indistinguishable from both groups $\left[F_{(2,17)}=3.914, p=0.04\right]$ (fig.5f,g). Projection-defined 191 neurons had a lower proportion of mature, mushroom-shaped dendritic spines than the general 192 population of adolescent neurons, more closely resembling adult neurons, although this 193 comparison did not reach statistical significance $\left[F_{(2,17)}=3.115, p=0.0704\right]$ (fig.5f,g). Thin-type spine 194 proportions did not differ between groups $\left[F_{(2,117)}=1.806, p=0.1945\right]$ (fig.5f,g).

195 We next characterized the morphological features of each dendritic spine subtype. 196 Mushroom-type spines on projection-defined neurons again more closely resembled adult spines 197 in length than same-age counterparts collected from a general layer $\mathrm{V}$ population $\left[F_{(2,17)}=8.578\right.$, $198 p=0.0027]$ (fig.5h). Spine diameters did not differ $[F<1]$ (fig.5h). Interestingly, spine volume was 199 largest in adult mice $\left[F_{(2,17)}=74.37, p<0.0001\right]$ (fig.5i). Thus, the morphology of mushroom-shaped 200 spines on projection-defined neurons in some ways resembled adult spines (in length), and in some 201 ways resembled their undefined adolescent counterparts (in volume).

202 We identified a similar pattern for stubby-shaped spines, in that stubby-type spines on 203 projection-defined neurons exhibited decreased length $\left[F_{(2,17)}=6.036, p=0.0105\right]$ and diameter $204[F(2,17)=15.94, p=0.0001]$ compared to the general population of same-age spines and more closely 
205 resembled adult spines (fig.5j). Stubby-type spine volume was similar in adult and projection-

206 defined adolescent populations, and far lower than a general adolescent population [Welch's

207 ANOVA $\left.W_{(2,10.19)}=18.76, p<0.0004\right]$ (fig.5k).

Lastly, projection-defined adolescent neurons had shorter thin-type spines than other

209 groups $\left[F_{(2,17)}=12.28, p=0.0005\right]$, with no group differences in diameters or volumes $[F s<1]$

210 (fig.5l,m). Thus, layer V PL neurons positioned within a BLA $\rightarrow P L \rightarrow D M S$ circuit exhibit distinctive

211 morphologies relative to a general population of layer V PL neurons.

212 We next asked: Do $\beta 1$-integrins stabilize neuron structure in a BLA $\rightarrow P L \rightarrow D M S$ circuit?

213 And in particular, during an adolescent sensitive period? To address these questions, we felt it

214 important to integrate into our experimental design a condition in which mice lost $\beta 1$-integrins prior

215 to adolescence, to complement conditions in which $\beta 1$-integrins were lost during or following

216 adolescence. Reducing $\beta 1$-integrins prior to adolescence via viral vector delivery is difficult due to

217 the small size of neonatal mice, so we instead crossed YFP+ Itgb1-flox mice with mice expressing

218 Emx1-Cre to achieve forebrain-specific loss of Itgb1 starting at embryonic day 11.5, when the Emx1

219 promoter becomes active ${ }^{30}$. Other groups of Itgb1-flox mice received either control or Cre-

220 expressing viral vectors as in prior figures and summarized in table 1 . Therefore, we were able to

221 compare the effects of embryonic-, adolescent-, and adult-onset $\beta 1$-integrin loss on layer V PL

222 neurons, including those positioned in a BLA $\rightarrow P L \rightarrow D M S$ circuit. A timeline reflecting gene silencing

223 and euthanasia timing is provided in fig.6a.

224 Dendritic spine imaging and reconstruction revealed that $\beta 1$-integrins in adolescence, but

225 not earlier or later, control dendritic spine density (fig.S1) and subtype distribution on PL neurons.

226 Proportions of mushroom- and thin-type spines were lower in both adolescent $\beta 1$-integrin-deficient

227 conditions (i.e., general layer $V$ neurons and those positioned in a BLA $\rightarrow P L \rightarrow D M S$ circuit), and

228 comparisons were statistically significant on projection-defined neurons [projection-defined

229 mushroom $\left(t_{(11)}=2.400, p=0.0373\right)$, thin $\left(t_{(11)}=2.235, p=0.0452\right)$; general population mushroom

$230\left(t_{(12)}=1.972, p=0.0721\right)$, thin $\left.\left(t_{(12)}=1.948, p=0.0752\right)\right]$ (fig.6b,c). $\beta 1$-integrin reduction in adolescence

231 accordingly elevated proportions of stubby-type spines, as expected [projection-defined 
$232 \quad\left(t_{(11)}=6.758, p<0.0001\right)$; general population $\left.\left(t_{(12)}=2.353, p=0.0365\right)\right]($ fig.6b,c). When we calculated

233 the proportion of mushroom to non-mushroom spines, projection-defined PL neurons again

234 suffered a significant loss $\left[t_{(11)}=2.745, p=0.0191\right]$, reflecting lower proportions of mature spines -

235 those likely to contain synapses (fig.6d).

236 In contrast to the adolescent groups, embryonic-onset and adult-onset $\beta 1$-integrin 237 reduction had no effects [ $p>0.05$ ] (fig. $6 b, c)$, even despite gross cortical layering deficits following 238 embryonic gene silencing. This phenomenon was first reported by ref. ${ }^{31}$ and is replicated in fig.S2.

239 Finally, we compared the volumes of dendritic spines in our adolescent groups. In addition

240 to changing spine proportions, $\beta 1$-integrin loss decreased the volumes of mature, mushroom-

241 shaped spines on projection-defined neurons [Welch's corrected $t_{(6.408)}=2.535, p=0.0419$ ], but not

242 in the general population $\left[t_{(12)}=0.3584, p=0.7262\right]($ fig.6e). Thus, $\beta 1$-integrins sustain typical

243 proportions and morphologies of mature, mushroom-shaped dendritic spines - those most likely to

244 contain synapses - within a developing BLA $\rightarrow P L \rightarrow D M S$ pathway (model in fig.6f). We speculate

245 that this function enables mature PL neurons to house stable synaptic connections necessary for 246 goal-directed action in adulthood. 
Across mammalian species, PFC development extends well into adolescence. Concurrent processes - dendritic spine elimination and stabilization - determine which inputs will be

250 maintained until adulthood ${ }^{32}$. We report that the cellular adhesion factor $\beta 1$-integrin in the PL 251 subregion of the PFC stabilizes dendritic spines on excitatory neurons during adolescent 252 development, and adolescent $\beta 1$-integrin presence is required for PL function in adulthood, 253 specifically in choosing actions based on their consequences. We find that the expression of 254 learned reward-related action strategies requires BLA inputs to the PL. This pattern led us to then 255 confirm that $\beta 1$-integrins on developing PL neurons receiving projections from the BLA and 256 projecting to the DMS, a primary striatal output controlling reward-related action ${ }^{27}$, are required for 257 healthy dendritic spine micro-architecture later in life. We envision that $\beta 1$-integrin-mediated 258 dendritic spine stabilization during adolescence provides structural substrates for synaptic 259 connections necessary for flexible action in adulthood.

\section{Cell adhesion during adolescence is required for flexible action later in life}

Both humans and rodents are sensitive to the relationships between actions and their 263 outcomes. Typical mice will change behaviors if causal relationships deteriorate, or if the value of 264 a given outcome declines. We report that $\beta 1$-integrins in the PL during adolescence are necessary 265 for these action strategies to manifest later in life. Specifically, reducing $\beta 1$-integrins in adolescence 266 rendered mice less likely to select actions based on outcome likelihood or value. Lesions and 267 inducible inactivation of the PL have the same effects ${ }^{13,14}$, but the current report is the first, to the 268 best of our knowledge, to establish the necessity of a cell adhesion receptor in these functions. 269 Reducing $\beta 1$-integrins in adulthood had no effects; thus, it appears likely that $\beta 1$-integrins support 270 goal-directed action via the stabilization of dendritic spines during adolescence, as opposed to any 271 acute function in synaptic plasticity in adulthood. Importantly, these findings in mature mice do not 272 negate the established function of the PL in flexible action selection in mature rodents; rather, they 273 rule out $\beta 1$-integrin as a factor that controls this capacity in the post-adolescent period. 
275 Flexible action requires BLA $\rightarrow$ PL connections

We found that silencing BLA $\rightarrow$ PL projections prohibited behavioral flexibility when mice

277 had to retrieve a newly formed outcome-related memory to guide choice behavior. Generally, these

278 findings are consistent with reports that pathway-specific ablation of BLA $\rightarrow P L$ projections renders

279 mice insensitive to outcome value ${ }^{24}\left(\right.$ but see $\left.^{33}\right)$, indicating their involvement in goal-directed action.

280 However, the PL is often thought to encode, but not necessarily retrieve, outcome-related

281 memories (reviewed in ${ }^{13}$ ), so our finding was in other ways unexpected. In seminal studies, lesions

282 were placed in the PL prior to instrumental training, or prior to any testing of goal-directed action ${ }^{34-}$

$283{ }^{36}$. This experimental design makes it difficult to disambiguate PL function(s) during different phases

284 of training and testing. More recent experiments used inducible inactivation techniques to test PL

285 function at different phases: during instrumental response training ${ }^{37}$, during the consolidation of 286 new memory ${ }^{38}$, and during the expression of that memory ${ }^{39}$. Shipman and colleagues

287 demonstrated that inducible inactivation of the PL impairs the retrieval of action-outcome memories

288 following brief but not extended training ${ }^{39}$. PL neurons may thus form an "early" memory engram

289 for outcome-related information as animals gain initial experience with a task, as has been reported

290 in fear conditioning contexts ${ }^{40}$. Meanwhile, the BLA represents specific outcome information that is

291 motivationally significant and necessary for choosing between options ${ }^{23}$. The contingency violation

292 in our task causes a transient "extinction burst," evidence of motivational salience ${ }^{41}$, so involvement

293 of the BLA in subsequent response prioritization is perhaps unsurprising. Our findings indicate that

294 BLA inputs to the PL help animals prioritize certain reward-seeking behaviors over others during

295 memory retrieval epochs.

297 Developmental $\beta 1$-integrins are necessary for the morphological features of PL neurons 298 positioned in a BLA $\rightarrow$ PL $\rightarrow$ DMS circuit

The ability to select actions based on their consequences requires BLA projections to the

$300 \mathrm{PL}$ (fig.4) and PL outputs to the DMS ${ }^{26,27}$. Further, the ability of PL $\rightarrow$ DMS projections to exert 301 control over goal-directed action ${ }^{26}$ is likely subject to input from the BLA, as inactivation of the BLA 
302 prevents learning-related plasticity at PL $\rightarrow$ DMS synapses ${ }^{24}$. We thus visualized developing 303 adolescent PL neurons positioned within this di-synaptic circuit, receiving projections from the BLA 304 and projecting to the DMS. We enumerated: thin-type dendritic spines, which exhibit rapid turnover 305 with a high potential for involvement in learning and memory; stubby-type dendritic spines, a 306 transitory phenotype that does not contain synapses; and mushroom-shaped spines, which house 307 high densities of glutamate receptors and stable synapses ${ }^{42}$. In some instances, these projection308 defined adolescent PL neurons more closely resembled mature PL neurons than a general 309 population of same-age adolescent neurons, for instance in the proportion of mature spines 310 detectable on dendrites.

311 One notable difference was that the mushroom-shaped spines on adult neurons were 312 larger in volume than those on adolescent neurons, including projection-defined adolescent 313 neurons. Larger spines are less motile and less plastic than other spines ${ }^{29}$, containing large stable 314 synapses $^{43}$ and a high density of AMPA receptors ${ }^{44,45}$. In contrast, smaller dendritic spines contain 315 relatively more NMDA receptors ${ }^{46}$, are highly sensitive to $\mathrm{Ca}^{2+-}$ mediated signaling ${ }^{47}$, and exhibit a 316 greater capacity for activity-dependent synaptic strengthening. Thus, adolescent neurons appear 317 to be primed for new learning, with high densities of small mushroom-shaped spines. 318 Reinforcement learning and the capacity for action selection according to action-outcome 319 contingencies improve throughout adolescence ${ }^{48,49}$. Likely mechanistic factors driving this 320 improvement include the strengthening of $\mathrm{BLA} \rightarrow \mathrm{PL}$ connectivity ${ }^{22}$, the elimination of extraneous 321 dendritic spines on PL neurons ${ }^{12,50}$, and as we reveal, the integrin-mediated maturation of dendritic 322 spines on PL neurons receiving input from the BLA and projecting to the DMS (fig.5).

323 To determine whether $\beta 1$-integrin presence controls PL neuron development during an 324 adolescent sensitive period, we integrated into our anatomical investigation a group of mice with 325 embryonic-onset gene silencing, to complement neurons that had undergone adolescent- or adult326 onset gene silencing. Despite the inclusion of these multiple conditions, $\beta 1$-integrin loss only in 327 adolescence detectably modified dendritic spine subtype presence, biasing dendritic spine 328 subtypes towards stubby-type spines at the expense of mushroom- and thin-type spines (those 329 with higher potential for synaptic presence). This effect was most profound in projection-defined 
330 neurons. Lower-than-typical proportions of mature spine types likely imperils signal fidelity from

331 incoming projections. We speculate that $\beta 1$-integrin tone in adolescence confers structural stability,

332 preserving synaptic efficacy ${ }^{44}, 45$. Supporting this perspective, $\beta 1$-integrins signal in neurons

333 through $\mathrm{p} 190 \mathrm{RhoGAP}$ and ROCK2 to encourage actin filament proliferation ${ }^{51}$, thereby maintaining 334 dendritic complexity ${ }^{10}$, and prefrontal cortical levels of these proteins peak in adolescence ${ }^{12}$.

335 Further, $\beta 1$-integrins promote interactions between the Arp2/3 complex and cortactin, supporting 336 actin branching and polymerization ${ }^{52-54}$, processes that would enable the maturation of spines from

337 an immature to mushroom morphology capable of housing synapses. Branching and actin 338 polymerization would also counter the retraction or elimination of mushroom-type spines. In vivo 339 imaging could disentangle precise $\beta 1$-integrin functions in developing neurons at far more granular 340 levels (e.g., see $\left.{ }^{50}\right)$.

$341 \quad$ Notably, $\beta 1$-integrins are involved in activity-dependent plasticity: For instance, integrin

342 ligands do not alter baseline physiological properties of cultured hippocampal neurons, but they 343 stabilize long-term potentiation (LTP) ${ }^{55}$. Further, integrin blocking antisera disrupts LTP-induced 344 actin polymerization and consolidation ${ }^{11,56}$. Multiple aspects of dendritic spine maturation in 345 adolescence are activity-dependent ${ }^{32}$, thus the recruitment of $\beta 1$-integrins seems sensible. 346 Meanwhile, loss of $\beta 1$-integrins before adolescence here had no effects on dendritic micro347 architecture. Similarly, $\beta 1$-integrins in embryogenesis do not appear to impact dendritic spine 348 densities on hippocampal CA1 neurons, even while they are involved in the proper maturation of 349 presynaptic physiology ${ }^{31}$, likely via the signaling partner talin ${ }^{57}$. We also found no effects of $\beta 1$ 350 integrin reduction in adulthood. This outcome might highlight the exquisite capacity of cell adhesion 351 factors to compensate for one another in mature organisms ${ }^{21}$.

\section{Conclusions}

354 To summarize, we find that presence of the cell adhesion molecule $\beta 1$-integrin during 355 adolescence is essential for flexible action later in life. We attribute this function to $\beta 1$-integrin356 mediated control dendritic spine restructuring that occurs during adolescent development, for 
357 instance, stabilizing PL neurons receiving input from the BLA. These neurons are necessary for 358 retrieving memories linking actions and outcomes. Thus, it seems likely that destabilizing their 359 capacity to house stable synapses (via developmental $\beta 1$-integrin loss) imperils the capacity of 360 mice to select actions based on likely outcomes.

361 Integrin signaling is thought to be dysregulated in substance use disorders ${ }^{58}$ and 362 schizophrenia ${ }^{59}$, diseases that often form or first present in adolescence and in which defects in 363 the capacity for goal-directed action are hallmark. Several $\beta 1$-integrin signaling partners are 364 pharmacologically modulable, opening avenues for new clinical applications. For instance, 365 stimulating $\beta 1$-integrin-mediated signaling pathways during adolescence could potentially combat 366 decision-making difficulties that are characteristic, and often reinforcing, of illness ${ }^{60}$. More broadly, 367 better understanding which cell adhesion molecules support adolescent brain development (and 368 how) may prove to be fertile ground in developing new therapeutic approaches. 
370 Subjects. Experiments used transgenic $\operatorname{ltbg} 1^{\text {tm1Efu }}$ (Itgb1-flox) mice bred on a mixed strain 371 background (C57BL/6J;129X1/SvJ). These mice have loxP sites flanking exon 3 of Itgb1; Cre 372 introduction deletes this exon ${ }^{16}$. Control mice were littermates that received a control viral vector, 373 rather than a Cre-expressing viral vector. Itgb1-flox mice were crossed with mice expressing YFP 374 under the Thy1 gene $\left(\mathrm{H}\right.$ line $\left.{ }^{28}\right)$ for dendritic spine imaging. Again, control mice were littermates that received a control viral vector, rather than a Cre-expressing viral vector, or littermates lacking Itgb1-

376 flox (see table 1 for conditions for each experiment). For embryonic-onset Itgb1 silencing, Itgb1377 flox/Thy1-YFP mice were crossed with mice expressing Emx1-Cre, allowing for forebrain-specific expression of Cre beginning at embryonic day $(E) 11.5^{30}$. Control mice in this experiment were Thy1-YFP/Cre+ littermates lacking Itgb1-flox. In this condition, Itgb1 would be unaffected. For projection-specific inactivation studies, C57BL/6J mice bred in-house from Jackson Labs stock were used, and viral vector conditions and controls are outlined in table 1. Throughout, mice were randomized to group.

Table 1 summarizes which mice were used in each experiment and ages of manipulations.

For Itgb1 knockdown experiments, mice infused with Cre-expressing viral vectors between postnatal days 21-24 are referred to as the "adolescent-onset" group because viral-mediated gene silencing would be expected to occur during adolescence, generally thought to start at postnatal day 28 in rodents. Meanwhile, Cre-expressing viral vectors were delivered at or soon after P56 in the adult condition to achieve gene silencing in adulthood.

Throughout, both sexes were used, and we did not detect sex differences. Mice were maintained on a $12 \mathrm{hr}$ light cycle (0700 on) and provided food and water ad libitum unless otherwise noted. Procedures were approved by the Emory University IACUC.

Stereotaxic surgery and viral vectors. Mice were anesthetized with ketamine/dexmedetomidine

$394(100 \mathrm{mg} / \mathrm{kg} / 0.5 \mathrm{mg} / \mathrm{kg}$, intraperitoneal injection (i.p.)) and placed in a digitized stereotaxic frame 395 (Stoelting). Small holes were drilled in the skull, and viral vectors were infused at AP+1.7mm,

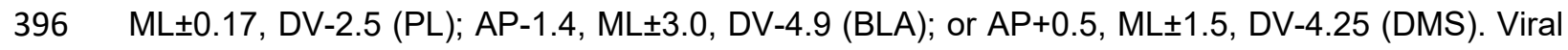


vectors were infused over $5 \mathrm{~min}$ in a volume of $0.5 \mu \mathrm{l}$. Viral vectors were supplied by UNC Viral

398 Vector Core or Addgene and are described in table 1. Syringes were left in place for $\geq 5$ min for PL 399 infusions, or $\geq 8$ min for BLA/DMS infusions, prior to removal and suturing. Mice were revived with 400 antisedan (3 mg/kg, i.p.) and left undisturbed for at least 3 weeks prior to euthanasia (for 401 immunoblotting or dendritic spine analysis) or behavioral experiments.

403 Immunoblotting. Mice were euthanized via rapid decapitation after brief anesthesia with 404 isoflurane. Brains were extracted, frozen at $-80^{\circ} \mathrm{C}$, and sectioned using a chilled brain matrix into $4051 \mathrm{~mm}$ slices. Tissue punches containing the PL were extracted using a $1 \mathrm{~mm}$ diameter tissue core. 406 Tissues were homogenized in lysis buffer $((200 \mu \mathrm{l}: 137 \mathrm{mM} \mathrm{NaCl}, 20 \mathrm{mM}$ tris- $\mathrm{HCl}(\mathrm{pH}=8), 1 \%$ 407 igepal, 10\% glycerol, 1:100 Phosphatase Inhibitor Cocktails 2 and 3 (Sigma), 1:1000 Protease 408 Inhibitor Cocktail (Sigma)), and stored at $-80^{\circ} \mathrm{C}$. Protein concentrations were determined using a 409 Bradford colorimetric assay kit (Pierce).

411 Following transfer to PVDF membrane, blots were blocked with $5 \%$ nonfat milk for $1 \mathrm{hr}$. Membranes 412 were subsequently incubated with primary antibodies: $\beta 1$-integrin (rabbit, Cell Signaling, 4706, 413 1:200), anti-RhoGAP p190 (mouse, Millipore, 05378, 1:1000), anti-phosphotyrosine (mouse, 414 generously provided by $A$. Koleske, clone 4G10, 1:500). p190RhoGAP is the predominant 415 phosphotyrosine-containing protein of $190 \mathrm{kD}$ recognized by the $4 \mathrm{G} 10$ antibody in mouse brain 416 tissue ${ }^{61}$ so we used the phosphotyrosine antibody to detect phosphorylated p190RhoGAP. After exposure to primary antibodies, membranes were incubated in horseradish 418 peroxidase secondary antibodies (anti-mouse, 1:10,000, Jackson ImmunoResearch; anti-rabbit, 419 1:10,000, Vector Labs) for $1 \mathrm{hr}$. Immunoreactivity was assessed using a chemiluminescence 420 substrate (Pierce) and measured using a ChemiDoc MP Imaging System (Bio-Rad). For $\beta 1$ 421 integrins, densitometry values were first normalized to a loading control, then normalized to the 422 control sample mean from the same membrane in order to control for variance in fluorescence 423 between gels. Phosphorylated p190RhoGAP levels were normalized to total p190RhoGAP. 
424 Immunoblots were replicated at least twice with concordant results, and proteins were detected at 425 expected molecular weights.

426 Instrumental response training. All mice were tested in adulthood (>P56). First, mice were food 427 restricted to $\sim 90 \%$ of their free-feeding body weight to motivate food-reinforced responding. Mice 428 were then trained to nose poke for 2 distinct food reinforcers (20 mg Bio-Serv Dustless Precision 429 Pellets, grain and chocolate) in Med Associates operant conditioning chambers equipped with 2 430 nose poke apertures and a separate food magazine. Responding on each aperture was reinforced 431 using a fixed ratio 1 (FR1) schedule of reinforcement, such that 30 pellets were available for 432 responding on each aperture. Sessions ended at $70 \mathrm{~min}$ or 60 pellets acquired. Training ended 433 after at least 7 sessions, when mice acquired all 60 pellets within 70 min. Response acquisition 434 curves represent responses/min for both nose poke apertures during the last 7 training sessions, 435 with no side or pellet preferences throughout.

437 Test for action-outcome response selection was conducted as previously described ${ }^{17,62}$. First, 4381 of the 2 apertures was available, and responding continued to be reinforced according to an FR1 439 schedule for $25 \mathrm{~min}$. As such, the action-outcome contingency associated with that aperture 440 remained intact. The following day, the other aperture was available for a 25 min session during 441 which the action-outcome association between that nose poke behavior and reward were violated. 442 In this case, pellets were delivered non-contingently at a rate matched to each animal's 443 reinforcement rate from the previous session. Responding was not reinforced. Thus, this nose poke 444 action becomes significantly less predictive of reinforcement than the other ${ }^{63}$. The apertures, as 445 well as the order of the "contingent" and "non-contingent" sessions, were counterbalanced.

446 Finally, both apertures were made available during a $15 \mathrm{~min}$ probe test conducted in 447 extinction the following day. Preferential engagement of the response that remained reinforced is 448 evidence of using contingency knowledge to guide choice. Meanwhile, engaging both responses 449 equivalently reflects a failure in response updating ${ }^{14}$. 
451 Outcome devaluation. A version of classical instrumental outcome devaluation was used, as

452 previously described ${ }^{64}$. Following response training, mice were placed into a clean, novel chamber

453 with 1-2 $\mathrm{g}$ of either grain- or chocolate-flavored pellets for $30 \mathrm{~min}$ (males) or $90 \mathrm{~min}$ (females),

454 devaluing that pellet. (In our experience, females require longer to consume this amount, hence

455 the longer prefeeding period.) Immediately following, mice were placed in the operant conditioning

456 chambers, and both apertures were available for a $15 \mathrm{~min}$ probe test conducted in extinction. Action

457 selection according to outcome value is reflected by preferential responding for the valued relative

458 to devalued pellet. If mice ate $\leq 0.2 \mathrm{~g}$ during the prefeeding period, the procedure was repeated.

459 Due to technical error, pellet consumption of only 16/21 mice was recorded.

461 Clozapine-N-Oxide (CNO) administration in vivo. In experiments using DREADDs, all mice 462 received CNO (Sigma; $1 \mathrm{mg} / \mathrm{kg}$, i.p., in $2 \%$ DMSO and saline), regardless of viral vector condition, 463 to equally expose animals to any unintended consequences of $\mathrm{CNO}^{65}$. For projection-specific 464 inactivation studies, CNO was administered 30 min prior to either the "non-contingent" session or 465 the probe test. The procedure was then repeated, with mice receiving CNO at the opposite time 466 point. The previously intact contingency was violated and vice versa. The control group is reported 467 as an average response rate for each control mouse across both injection time points.

469 Histology. For analysis of viral vector spread, mice were transcardially perfused under deep 470 anesthesia with ketamine/xylazine $(120 \mathrm{mg} / \mathrm{kg} / 10 \mathrm{mg} / \mathrm{kg}$, i.p.), prior to brain incubation in $4 \%$ 471 paraformaldehyde. Brains were next transferred to $30 \% \mathrm{w} / \mathrm{v}$ sucrose solution, then were sectioned 472 on a Leica microtome held at $-15^{\circ} \mathrm{C}$ into $50 \mu \mathrm{m}$ sections, mounted, and coverslipped. The mCherry 473 tag was visualized. Immunohistochemistry for mCherry (mouse, 1:1000, Takara; goat anti-mouse474 alexa594, 1:500, Invitrogen) was used to delineate viral vector spread, as needed.

476 Electrophysiology. Mice were euthanized by rapid decapitation after brief anesthesia with 477 isoflurane. Brains were extracted and sectioned using a vibrating microtome (Leica) into $300 \mu \mathrm{m}$ 
478 sections. Sections containing the $\mathrm{BLA}$ were incubated in $95 \% \mathrm{O}_{2} / 5 \% \mathrm{CO}_{2}$ oxygenated $32^{\circ} \mathrm{C}$ 479 sectioning ACSF for $1 \mathrm{hr}$ before recording (for details, see ${ }^{66}$ ).

480 Brain sections were transferred to a recording chamber mounted on the stage of a Leica 481 microscope and perfused with recording ACSF at a rate of $\sim 2 \mathrm{ml} / \mathrm{min}$. BLA $\rightarrow P L$ projection neurons 482 were identified by the expression of mCherry using a Leica STP6000 epifluorescence microscope. 483 Whole cell patch clamp recordings were performed using a MultiClamp 700B amplifier, a Digidata 4841550 digitizer and pClamp 10.6 software (Molecular Devices). Recording pipettes have resistance 485 of 4 6 $\mathrm{M} \Omega$ when filled with potassium gluconate-based patch solution (in mM): K-Gluconate (130), $\mathrm{KCl}$ (2), HEPES (10), $\mathrm{MgCl}_{2}$ (3), phosphocreatine (5), K-ATP (2), and NaGTP (0.2). The patch 487 solution was adjusted to $\mathrm{pH} 7.3$ and had an osmolarity of $280-290$ mOsm. $0.3 \%$ biocytin was 488 included in the patch solution to stain and localize patched BLA neurons. Membrane potential was 489 current clamped at $-60 \mathrm{mV}$ for baseline recordings and input resistance was monitored by observing 490 membrane responses to hyperpolarization current injections (100-200 pA, $0.5 \mathrm{~s})$.

To examine the inhibitory effects of Gi-DREADD activation on BLA neurons, we recorded 4923 measures before and during $\mathrm{CNO}(10 \mu \mathrm{M})$ application: 1) membrane potential hyperpolarization; 493 2) rheobase, the minimum current required to generate a single action potential in a ramp current 494 injection protocol (250 ms); and 3) the number of spikes in response to current injection steps (1 s 495 duration, delta 30-60 pA). Whole-cell access resistances were deemed acceptable if current clamp 496 measurements were $<20 \mathrm{M} \Omega$ and changed $<15 \%$ throughout recording. Analysis was performed 497 offline using Clampfit 10.6 (Molecular Devices).

499 Dendritic spine imaging. Mice were euthanized by rapid decapitation after brief anesthesia with 500 isoflurane, and brains were extracted and submerged in $4 \%$ paraformaldehyde. Brains were next 501 transferred to $30 \% \mathrm{w} / \mathrm{v}$ sucrose solution, then were sectioned on a Leica microtome held at $-15^{\circ} \mathrm{C}$ 502 into $50 \mu \mathrm{m}$ sections, mounted, and coverslipped. Unobstructed dendritic segments co-expressing 503 mCherry and YFP (or just YFP in Emx mutant mice) were imaged on a spinning disk confocal 504 (VisiTech International) on a Leica DM 5500B microscope. Z-stacks were collected with a 100x 505 1.4NA objective using a $0.1 \mu \mathrm{m}$ step size, sampling above and below the dendrite. After imaging, 
506 we confirmed at 10x that the image was collected from the PL. For each animal, 5-12 independent

507 basal dendrite segments, located $25-150 \mu \mathrm{m}$ from the soma, were imaged.

508 Dendritic spines were reconstructed in 3-D using Imaris software and previously described 509 methods ${ }^{67}$. Images were not manipulated prior to Imaris processing. Each experiment was scored 510 by a single blinded rater. Each protrusion $\leq 4.5 \mu \mathrm{m}$ in length was considered a spine. Bifurcated 511 spines were considered singular units. Dendritic spines less than $0.6 \mu \mathrm{m}$ in length were defined as 512 stubby. If spine length was greater than $0.6 \mu \mathrm{m}$, spine classification was dependent on head 513 diameter: spines with a head diameter more than 2 times the neck diameter were classified as 514 mushroom, and spines with a head diameter less than 2 times the neck diameter were classified 515 as $\operatorname{thin}^{68}$.

517 Statistics. All statistics were performed using GraphPad Prism or SPSS. Immunoblotting results 518 and response ratios in the devaluation experiment were analyzed using a 2-tailed, unpaired t-test.

519 ANOVAs were used to compare response rates in other behavioral experiments, with repeating 520 measures (RM) when appropriate. Tukey's post-hoc tests were used in the case of significant 521 interactions or main effects with $>2$ groups and are indicated in the figures. Values $>2$ standard 522 deviations above the mean were considered outliers and excluded. For electrophysiological 523 experiments, hyperpolarization was analyzed using a 1-sample t-test using 0 as a baseline. 524 Rheobases before and during CNO were compared by a 2-tailed, paired t-test. The numbers of 525 spikes in response to current steps were plotted and compared using a 2-way RM ANOVA followed 526 by Bonferroni post-hoc tests.

527 Proportions of each dendritic spine subtype were generated by dividing a given spine 528 subtype number by the total spine number for that dendritic segment. For dendritic spine subtype 529 proportion and morphometric analyses, each animal contributed one value, reflecting the average 530 of its dendrites. For initial subtype and morphometric comparisons, a 1-way ANOVA was used. Any 531 significant effects were explored using Tukey's post-hoc analyses. In the case of unequal 532 variances, as analyzed by a Brown-Forsythe test, a Welch's ANOVA was used instead, with 533 Dunnett T3 post-hocs. All knockdown comparisons were analyzed using 2-tailed, unpaired t-tests. 
bioRxiv preprint doi: https://doi.org/10.1101/2021.07.12.452062; this version posted July 12, 2021. The copyright holder for this preprint (which was not certified by peer review) is the author/funder, who has granted bioRxiv a license to display the preprint in perpetuity. It is made available under aCC-BY 4.0 International license.

534 Welch's correction was used in the case of unequal variances. All experiments were conducted in 535 at least 2 independent cohorts of mice. Sample sizes were determined based on power analyses 536 and prior similar experiments in our laboratory. 


\section{Acknowledgments}

538 We thank Dr. A. J. Koleske for the phosphotyrosine kinase antibody, Ellen P. Woon and H.

539 Arrowood for assistance with dendritic spine reconstruction, Meghan Wynne for assistance with

540 pilot experiments, and Dan C. Li for his thoughtful contributions to the manuscript. The work in the

541 S.L.G. lab is supported by NIH T32 GM008602, F30 MH117878, F31 MH109208, R01 MH117103,

542 and P50 MH100023. The Yerkes National Primate Research Center is supported by the Office of

543 Research Infrastructure Programs/OD P51 OD011132. Research reported in this publication was

544 also supported in part by the Emory University Integrated Cellular Imaging Core and Children's

545 Healthcare of Atlanta.

\section{$546 \quad$ Competing Interests}

547 The authors report no competing interests.

\section{References}

549 1. Crews F, He J, Hodge C. Adolescent cortical development: A critical period of

550 vulnerability for addiction. Pharmacology Biochemistry and Behavior. 2007;86(2):189-99.

551 doi: https://doi.org/10.1016/j.pbb.2006.12.001.

552 2. Spear LP. The adolescent brain and age-related behavioral manifestations. Neuroscience \& Biobehavioral Reviews. 2000;24(4):417-63. doi: https://doi.org/10.1016/S0149-7634(00)00014-2.

3. Kessler RC, Angermeyer M, Anthony JC, De Graaf R, Demyttenaere K, Gasquet I, De Girolamo G, Gluzman S, Gureje O, Haro JM, Kawakami N, Karam A, Levinson D, Medina Mora ME, Oakley Browne MA, Posada-Villa J, Stein DJ, Adley Tsang CH, AguilarGaxiola S, Alonso J, Lee S, Heeringa S, Pennell B-E, Berglund P, Gruber MJ, Petukhova $\mathrm{M}$, Chatterji S, Ustün TB. Lifetime prevalence and age-of-onset distributions of mental disorders in the World Health Organization's World Mental Health Survey Initiative. World Psychiatry. 2007;6(3):168-76. PubMed PMID: 18188442.

4. Penzes $P$, Cahill ME, Jones KA, VanLeeuwen J-E, Woolfrey KM. Dendritic spine pathology in neuropsychiatric disorders. Nature neuroscience. 2011;14(3):285-93. doi: 10.1038/nn.2741. PubMed PMID: PMC3530413.

5. Glausier JR, Lewis DA. Dendritic Spine Pathology in Schizophrenia. Neuroscience. 2013;251:90-107. doi: 10.1016/j.neuroscience.2012.04.044. PubMed PMID: PMC3413758.

6. MacDonald ML, Alhassan J, Newman JT, Richard M, Gu H, Kelly RM, Sampson AR, Fish KN, Penzes P, Wills ZP, Lewis DA, Sweet RA. Selective Loss of Smaller Spines in Schizophrenia. American Journal of Psychiatry. 2017;174(6):586-94. doi: 10.1176/appi.ajp.2017.16070814.

7. Humphrey JD, Dufresne ER, Schwartz MA. Mechanotransduction and extracellular matrix homeostasis. Nat Rev Mol Cell Biol. 2014;15(12):802-12. doi: 10.1038/nrm3896. PubMed PMID: 25355505. 
575 8. Ivankovic-Dikic I, Gronroos E, Blaukat A, Barth B-U, Dikic I. Pyk2 and FAK regulate neurite outgrowth induced by growth factors and integrins. Nat Cell Biol. 2000;2(9):57481.

9. Pasterkamp RJ, Peschon JJ, Spriggs MK, Kolodkin AL. Semaphorin 7A promotes axon outgrowth through integrins and MAPKs. Nature. 2003;424(6947):398-405. doi: 10.1038/nature01790.

10. Warren MS, Bradley WD, Gourley SL, Lin Y-C, Simpson MA, Reichardt LF, Greer CA, Taylor JR, Koleske AJ. Integrin $\beta 1$ signals through Arg to regulate postnatal dendritic arborization, synapse density, and behavior. The Journal of Neuroscience. 2012;32(8):2824-34. doi: 10.1523/JNEUROSCI.3942-11.2012. PubMed PMID: PMC3313657.

11. Kramár EA, Lin B, Rex CS, Gall CM, Lynch G. Integrin-driven actin polymerization consolidates long-term potentiation. Proceedings of the National Academy of Sciences. 2006;103(14):5579-84. doi: 10.1073/pnas.0601354103.

12. Shapiro LP, Parsons RG, Koleske AJ, Gourley SL. Differential expression of cytoskeletal regulatory factors in the adolescent prefrontal cortex: Implications for cortical development. J Neurosci Res. 2017;95(5):1123-43. doi: 10.1002/jnr.23960. PubMed PMID: 27735056; PMCID: PMC5352542.

13. Woon EP, Sequeira MK, Barbee BR, Gourley SL. Involvement of the rodent prelimbic and medial orbitofrontal cortices in goal-directed action: A brief review. Journal of Neuroscience Research. 2020;98(6):1020-30. doi: https://doi.org/10.1002/jnr.24567.

14. Balleine BW, O'Doherty JP. Human and Rodent Homologies in Action Control: Corticostriatal Determinants of Goal-Directed and Habitual Action. Neuropsychopharmacology. 2010;35(1):48-69. doi: 10.1038/npp.2009.131. PubMed PMID: PMC3055420.

15. Hart G, Leung BK, Balleine BW. Dorsal and ventral streams: the distinct role of striatal subregions in the acquisition and performance of goal-directed actions. Neurobiology of learning and memory. 2014;108:104-18. doi: 10.1016/j.nlm.2013.11.003. PubMed PMID: 24231424.

16. Raghavan S, Bauer C, Mundschau G, Li Q, Fuchs E. Conditional ablation of beta1 integrin in skin. Severe defects in epidermal proliferation, basement membrane formation, and hair follicle invagination. The Journal of cell biology. 2000;150(5):1149-60. doi: 10.1083/jcb.150.5.1149. PubMed PMID: 10974002.

17. DePoy LM, Shapiro LP, Kietzman HW, Roman KM, Gourley SL. $\beta 1$-integrins in the developing orbitofrontal cortex are necessary for expectancy updating in mice. The Journal of Neuroscience. 2019:3072-18. doi: 10.1523/jneurosci.3072-18.2019.

18. Cahoy JD, Emery B, Kaushal A, Foo LC, Zamanian JL, Christopherson KS, Xing Y, Lubischer JL, Krieg PA, Krupenko SA, Thompson WJ, Barres BA. A Transcriptome Database for Astrocytes, Neurons, and Oligodendrocytes: A New Resource for Understanding Brain Development and Function. The Journal of Neuroscience. 2008;28(1):264. doi: 10.1523/JNEUROSCI.4178-07.2008.

19. Bradley WD, Hernández SE, Settleman J, Koleske AJ. Integrin Signaling through Arg Activates p190RhoGAP by Promoting Its Binding to p120RasGAP and Recruitment to the Membrane. Molecular Biology of the Cell. 2006;17(11):4827-36.

20. Schuster T, Krug M, Stalder M, Hackel N, Gerardy-Schahn R, Schachner M. Immunoelectron microscopic localization of the neural recognition molecules L1, NCAM, and its isoform NCAM180, the NCAM-associated polysialic acid, beta1 integrin and the extracellular matrix molecule tenascin- $R$ in synapses of the adult rat hippocampus. $J$ Neurobiol. 2001;49(2):142-58. doi: 10.1002/neu.1071. PubMed PMID: 11598921. 
21. Mortillo S, Elste A, Ge Y, Patil SB, Hsiao K, Huntley GW, Davis RL, Benson DL. Compensatory redistribution of neuroligins and $\mathrm{N}$-cadherin following deletion of synaptic ß1-integrin. J Comp Neurol. 2012;520(9):2041-52. doi: 10.1002/cne.23027. PubMed PMID: 22488504; PMCID: PMC3496382.

22. Cunningham MG, Bhattacharyya S, Benes FM. Amygdalo-cortical sprouting continues into early adulthood: Implications for the development of normal and abnormal function during adolescence. Journal of Comparative Neurology. 2002;453(2):116-30. doi: 10.1002/cne.10376.

23. Wassum KM, Izquierdo A. The basolateral amygdala in reward learning and addiction. Neurosci Biobehav Rev. 2015;57:271-83. doi: 10.1016/j.neubiorev.2015.08.017. PubMed PMID: 26341938.

24. Fisher SD, Ferguson LA, Bertran-Gonzalez J, Balleine BW. Amygdala-Cortical Control of Striatal Plasticity Drives the Acquisition of Goal-Directed Action. Current Biology. 2020;30(22):4541-6.e5. doi: https://doi.org/10.1016/j.cub.2020.08.090.

25. Cheriyan J, Kaushik MK, Ferreira AN, Sheets PL. Specific Targeting of the Basolateral Amygdala to Projectionally Defined Pyramidal Neurons in Prelimbic and Infralimbic Cortex. eNeuro. 2016;3(2):ENEURO.0002-16.2016. doi: 10.1523/ENEURO.000216.2016. PubMed PMID: 27022632.

26. Hart G, Bradfield LA, Balleine BW. Prefrontal Corticostriatal Disconnection Blocks the Acquisition of Goal-Directed Action. The Journal of Neuroscience. 2018;38(5):1311-22. doi: 10.1523/jneurosci.2850-17.2017.

27. Hart G, Bradfield LA, Fok SY, Chieng B, Balleine BW. The Bilateral Prefronto-striatal Pathway Is Necessary for Learning New Goal-Directed Actions. Current Biology. 2018;28(14):2218-29.e7. doi: 10.1016/j.cub.2018.05.028.

28. Feng G, Mellor RH, Bernstein M, Keller-Peck C, Nguyen QT, Wallace M, Nerbonne JM, Lichtman JW, Sanes JR. Imaging Neuronal Subsets in Transgenic Mice Expressing Multiple Spectral Variants of GFP. Neuron. 2000;28(1):41-51. doi: https://doi.org/10.1016/S0896-6273(00)00084-2.

29. Holtmaat AJ, Trachtenberg JT, Wilbrecht L, Shepherd GM, Zhang X, Knott GW, Svoboda $K$. Transient and persistent dendritic spines in the neocortex in vivo. Neuron. 2005;45(2):279-91. doi: 10.1016/j.neuron.2005.01.003. PubMed PMID: 15664179.

30. Gorski JA, Talley T, Qiu M, Puelles L, Rubenstein JLR, Jones KR. Cortical Excitatory Neurons and Glia, But Not GABAergic Neurons, Are Produced in the Emx1-Expressing Lineage. The Journal of Neuroscience. 2002;22(15):6309.

31. Huang Z, Shimazu K, Woo NH, Zang K, Müller U, Lu B, Reichardt LF. Distinct Roles of the $\beta 1$-Class Integrins at the Developing and the Mature Hippocampal Excitatory Synapse. The Journal of neuroscience : the official journal of the Society for Neuroscience. 2006;26(43):11208-19. doi: 10.1523/JNEUROSCI.3526-06.2006. PubMed PMID: PMC2693048.

32. Chen C-C, Lu J, Zuo Y. Spatiotemporal dynamics of dendritic spines in the living brain. Front Neuroanat. 2014;8:28-. doi: 10.3389/fnana.2014.00028. PubMed PMID: 24847214.

33. Coutureau E, Marchand AR, Di Scala G. Goal-directed responding is sensitive to lesions to the prelimbic cortex or basolateral nucleus of the amygdala but not to their disconnection. Behavioral Neuroscience. 2009;123(2):443-8. doi: 10.1037/a0014818.

34. Balleine BW, Dickinson A. Goal-directed instrumental action: contingency and incentive learning and their cortical substrates. Neuropharmacology. 1998;37(4):407-19. doi: https://doi.org/10.1016/S0028-3908(98)00033-1. 
671

35. Corbit LH, Balleine BW. The role of prelimbic cortex in instrumental conditioning. Behav Brain Res. 2003;146(1-2):145-57. doi: 10.1016/j.bbr.2003.09.023. PubMed PMID: 14643467.

36. Ostlund SB, Balleine BW. Lesions of Medial Prefrontal Cortex Disrupt the Acquisition But Not the Expression of Goal-Directed Learning. The Journal of Neuroscience. 2005;25(34):7763-70. doi: 10.1523/jneurosci.1921-05.2005.

37. Baldwin AE, Sadeghian K, Kelley AE. Appetitive instrumental learning requires coincident activation of NMDA and dopamine D1 receptors within the medial prefrontal cortex. $J$ Neurosci. 2002;22(3):1063-71. doi: 10.1523/jneurosci.22-03-01063.2002. PubMed PMID: $11826135 ;$ PMCID: PMC6758518.

38. Hart G, Balleine BW. Consolidation of Goal-Directed Action Depends on MAPK/ERK Signaling in Rodent Prelimbic Cortex. The Journal of neuroscience : the official journal of the Society for Neuroscience. 2016;36(47):11974-86. doi: 10.1523/JNEUROSCI.177216.2016. PubMed PMID: 27881782.

39. Shipman ML, Trask S, Bouton ME, Green JT. Inactivation of prelimbic and infralimbic cortex respectively affects minimally-trained and extensively-trained goal-directed actions. Neurobiology of learning and memory. 2018;155:164-72. doi: 10.1016/j.nlm.2018.07.010. PubMed PMID: 30053577.

40. Giannotti G, Heinsbroek JA, Yue AJ, Deisseroth K, Peters J. Prefrontal cortex neuronal ensembles encoding fear drive fear expression during long-term memory retrieval. Scientific Reports. 2019;9(1):10709. doi: 10.1038/s41598-019-47095-7.

41. Zimmermann KS, Hsu C-C, Gourley SL. Strain commonalities and differences in response-outcome decision making in mice. Neurobiology of learning and memory. 2016;131:101-8. doi: 10.1016/j.nlm.2016.03.016. PubMed PMID: 27003118.

42. Kasai H, Fukuda M, Watanabe S, Hayashi-Takagi A, Noguchi J. Structural dynamics of dendritic spines in memory and cognition. Trends in Neurosciences. 2010;33(3):121-9. doi: 10.1016/j.tins.2010.01.001.

43. Harris KM, Stevens JK. Dendritic spines of CA 1 pyramidal cells in the rat hippocampus: serial electron microscopy with reference to their biophysical characteristics. The Journal of neuroscience : the official journal of the Society for Neuroscience. 1989;9(8):2982-97. doi: 10.1523/JNEUROSCI.09-08-02982.1989. PubMed PMID: 2769375.

44. Matsuzaki M, Ellis-Davies GC, Nemoto T, Miyashita Y, lino M, Kasai H. Dendritic spine geometry is critical for AMPA receptor expression in hippocampal CA1 pyramidal neurons. Nature neuroscience. 2001;4(11):1086-92. doi: 10.1038/nn736. PubMed PMID: 11687814.

45. Noguchi J, Matsuzaki M, Ellis-Davies GC, Kasai H. Spine-neck geometry determines NMDA receptor-dependent Ca2+ signaling in dendrites. Neuron. 2005;46(4):609-22. doi: 10.1016/j.neuron.2005.03.015. PubMed PMID: 15944129; PMCID: PMC4151245.

46. Kasai H, Matsuzaki M, Noguchi J, Yasumatsu N, Nakahara H. Structure-stability-function relationships of dendritic spines. Trends Neurosci. 2003;26(7):360-8. doi: 10.1016/s01662236(03)00162-0. PubMed PMID: 12850432.

47. Nimchinsky EA, Yasuda R, Oertner TG, Svoboda K. The number of glutamate receptors opened by synaptic stimulation in single hippocampal spines. J Neurosci. 2004;24(8):2054-64. doi: 10.1523/jneurosci.5066-03.2004. PubMed PMID: 14985448; PMCID: PMC6730404.

48. Afshar NM, Keip AJ, Taylor JR, Lee D, Groman SM. Reinforcement Learning during Adolescence in Rats. J Neurosci. 2020;40(30):5857-70. doi: 10.1523/jneurosci.091020.2020. PubMed PMID: 32601244; PMCID: PMC7380962. 
49. Naneix F, Marchand AR, Di Scala G, Pape J-R, Coutureau E. Parallel maturation of goaldirected behavior and dopaminergic systems during adolescence. The Journal of neuroscience : the official journal of the Society for Neuroscience. 2012;32(46):16223-32. doi: 10.1523/JNEUROSCI.3080-12.2012. PubMed PMID: 23152606.

50. Johnson CM, Loucks FA, Peckler H, Thomas AW, Janak PH, Wilbrecht L. Long-range orbitofrontal and amygdala axons show divergent patterns of maturation in the frontal cortex across adolescence. Developmental Cognitive Neuroscience. 2016;18:113-20. doi: https://doi.org/10.1016/j.dcn.2016.01.005.

51. Sfakianos MK, Eisman A, Gourley SL, Bradley WD, Scheetz AJ, Settleman J, Taylor JR, Greer CA, Williamson A, Koleske AJ. Inhibition of Rho via Arg and p190RhoGAP in the Postnatal Mouse Hippocampus Regulates Dendritic Spine Maturation, Synapse and Dendrite Stability, and Behavior. The Journal of Neuroscience. 2007;27(41):10982.

52. MacGrath SM, Koleske AJ. Arg/Abl2 Modulates the Affinity and Stoichiometry of Binding of Cortactin to F-Actin. Biochemistry. 2012;51(33):6644-53. doi: 10.1021/bi300722t. PubMed PMID: PMC3556572.

53. Weaver AM, Karginov AV, Kinley AW, Weed SA, Li Y, Parsons JT, Cooper JA. Cortactin promotes and stabilizes Arp2/3-induced actin filament network formation. Current Biology.11(5):370-4. doi: 10.1016/S0960-9822(01)00098-7.

54. Shaw JE, Kilander MBC, Lin YC, Koleske AJ. Abl2:cortactin interactions regulate dendritic spine stability via control of a stable filamentous actin pool. J Neurosci. 2021. doi: 10.1523/jneurosci.2472-20.2021. PubMed PMID: 33622779.

55. Bahr BA, Staubli U, Xiao P, Chun D, Ji ZX, Esteban ET, Lynch G. Arg-Gly-Asp-Serselective adhesion and the stabilization of long-term potentiation: pharmacological studies and the characterization of a candidate matrix receptor. The Journal of neuroscience : the official journal of the Society for Neuroscience. 1997;17(4):1320-9. doi: 10.1523/JNEUROSCI.17-04-01320.1997. PubMed PMID: 9006975.

56. Ackermann M, Matus A. Activity-induced targeting of profilin and stabilization of dendritic spine morphology. Nature Neuroscience. 2003;6(11):1194-200. doi: 10.1038/nn1135.

57. Morgan JR, Di Paolo G, Werner H, Shchedrina VA, Pypaert M, Pieribone VA, De Camilli P. A role for talin in presynaptic function. The Journal of cell biology. 2004;167(1):43-50. doi: 10.1083/jcb.200406020. PubMed PMID: 15479735.

58. Drgon T, Zhang P-W, Johnson C, Walther D, Hess J, Nino M, Uhl GR. Genome wide association for addiction: replicated results and comparisons of two analytic approaches. PloS one. 2010;5(1):e8832-e. doi: 10.1371/journal.pone.0008832. PubMed PMID: 20098672.

59. Jaffe AE, Straub RE, Shin JH, Tao R, Gao Y, Collado-Torres L, Kam-Thong T, Xi HS, Quan J, Chen Q, Colantuoni C, Ulrich WS, Maher BJ, Deep-Soboslay A, Cross AJ, Brandon NJ, Leek JT, Hyde TM, Kleinman JE, Weinberger DR. Developmental and genetic regulation of the human cortex transcriptome illuminate schizophrenia pathogenesis. Nature Neuroscience. 2018;21(8):1117-25. doi: 10.1038/s41593-0180197-y.

60. Cáceda R, Nemeroff CB, Harvey PD. Toward an Understanding of Decision Making in Severe Mental Illness. The Journal of Neuropsychiatry and Clinical Neurosciences. 2014;26(3):196-213. doi: 10.1176/appi.neuropsych.12110268.

61. Brouns MR, Matheson SF, Settleman J. p190 RhoGAP is the principal Src substrate in brain and regulates axon outgrowth, guidance and fasciculation. Nat Cell Biol. 2001;3(4):361-7. doi: 10.1038/35070042. PubMed PMID: 11283609. 
62. Gourley SL, Swanson AM, Jacobs AM, Howell JL, Mo M, DiLeone RJ, Koleske AJ, Taylor JR. Action control is mediated by prefrontal BDNF and glucocorticoid receptor binding. Proceedings of the National Academy of Sciences of the United States of America. 2012;109(50):20714-9. doi: 10.1073/pnas.1208342109. PubMed PMID: PMC3528547.

63. Butkovich LM, DePoy LM, Allen AG, Shapiro LP, Swanson AM, Gourley SL. Adolescentonset GABAA a1 silencing regulates reward-related decision making. The European journal of neuroscience. 2015;42(4):2114-21. doi: 10.1111/ejn.12995. PubMed PMID: 26096050.

64. Balleine BW, Killcross AS, Dickinson A. The effect of lesions of the basolateral amygdala on instrumental conditioning. The Journal of neuroscience : the official journal of the Society for Neuroscience. 2003;23(2):666-75. doi: 10.1523/JNEUROSCI.23-0200666.2003. PubMed PMID: 12533626.

65. Gomez JL, Bonaventura J, Lesniak W, Mathews WB, Sysa-Shah P, Rodriguez LA, Ellis RJ, Richie CT, Harvey BK, Dannals RF, Pomper MG, Bonci A, Michaelides M. Chemogenetics revealed: DREADD occupancy and activation via converted clozapine. Science. 2017;357(6350):503-7. doi: 10.1126/science.aan2475.

66. Guo J-D, O'Flaherty BM, Rainnie DG. Serotonin gating of cortical and thalamic glutamate inputs onto principal neurons of the basolateral amygdala. Neuropharmacology. 2017;126:224-32. doi: 10.1016/j.neuropharm.2017.09.013. PubMed PMID: 28899729.

67. Gourley SL, Swanson AM, Koleske AJ. Corticosteroid-induced neural remodeling predicts behavioral vulnerability and resilience. J Neurosci. 2013;33(7):3107-12. doi: 10.1523/jneurosci.2138-12.2013. PubMed PMID: 23407965; PMCID: PMC3711631.

68. Cooper MA, Koleske AJ. Ablation of ErbB4 from excitatory neurons leads to reduced dendritic spine density in mouse prefrontal cortex. J Comp Neurol. 2014;522(14):335162. doi: 10.1002/cne.23615. PubMed PMID: 24752666; PMCID: PMC4107058.

69. Rosen GD, Williams, A.G., Capra, J.A., Connolly, M.T., Cruz, B., Lu, L., Airey, D.C., Kulkarn,i K., Williams, R.W. . The Mouse Brain Library @ www.mbl.org. Int Mouse Genome Conference. 2000;14(166).

70. Lein ES, Hawrylycz MJ, Ao N, Ayres M, Bensinger A, Bernard A, Boe AF, Boguski MS, Brockway KS, Byrnes EJ, Chen L, Chen L, Chen T-M, Chi Chin M, Chong J, Crook BE, Czaplinska A, Dang CN, Datta S, Dee NR, Desaki AL, Desta T, Diep E, Dolbeare TA, Donelan MJ, Dong H-W, Dougherty JG, Duncan BJ, Ebbert AJ, Eichele G, Estin LK, Faber C, Facer BA, Fields R, Fischer SR, Fliss TP, Frensley C, Gates SN, Glattfelder KJ, Halverson KR, Hart MR, Hohmann JG, Howell MP, Jeung DP, Johnson RA, Karr PT, Kawal R, Kidney JM, Knapik RH, Kuan CL, Lake JH, Laramee AR, Larsen KD, Lau C, Lemon TA, Liang AJ, Liu Y, Luong LT, Michaels J, Morgan JJ, Morgan RJ, Mortrud MT, Mosqueda NF, Ng LL, Ng R, Orta GJ, Overly CC, Pak TH, Parry SE, Pathak SD, Pearson OC, Puchalski RB, Riley ZL, Rockett HR, Rowland SA, Royall JJ, Ruiz MJ, Sarno NR, Schaffnit K, Shapovalova NV, Sivisay T, Slaughterbeck CR, Smith SC, Smith KA, Smith BI, Sodt AJ, Stewart NN, Stumpf K-R, Sunkin SM, Sutram M, Tam A, Teemer CD, Thaller C, Thompson CL, Varnam LR, Visel A, Whitlock RM, Wohnoutka PE, Wolkey CK, Wong VY, Wood M, Yaylaoglu MB, Young RC, Youngstrom BL, Feng Yuan X, Zhang $\mathrm{B}$, Zwingman TA, Jones AR. Genome-wide atlas of gene expression in the adult mouse brain. Nature. 2007;445(7124):168-76. doi: 10.1038/nature05453. 

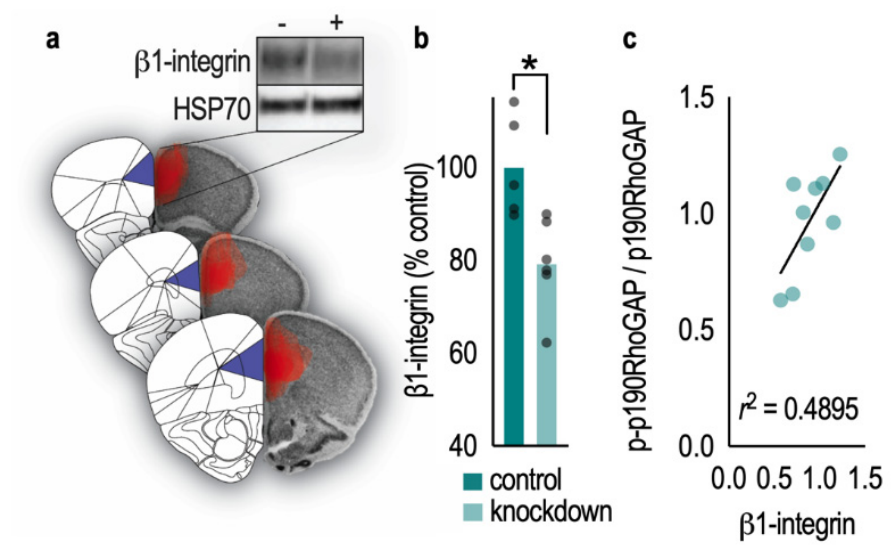

Figure 1. Itgb1 knockdown reduces $\beta 1$-integrin protein levels. a. CaMKIla-AAVs \pm Cre were

815 infused bilaterally into PL of Itgb1-flox mice. (left) Images from Allen Brain Atlas (from left: +2.71

$816 \mathrm{~mm},+2.22 \mathrm{~mm}$, and $+1.98 \mathrm{~mm}$ relative to bregma) depicting the $\mathrm{PL}$ (purple). (right) Overlays of

817 viral vector spread (red) encompassing the PL from mice in this report on images from the Mouse

818 Brain Library ${ }^{69}$. All cohorts exhibited consistent viral vector localization. (top right) Representative

819 blots. b. Viral-mediated Itgb1 silencing reduced $\beta 1$-integrin protein levels in PFC tissue punches by

$820 \sim 21 \%$. Incomplete protein loss was expected, given that samples contained transduced and

821 unaffected cells, and glial integrins were spared. c. $\beta 1$-integrin protein levels correlated with

822 phosphorylation (activation) of the neuronal substrate p190RhoGAP. Bars represent means, and

823 symbols represent individual mice. ${ }^{*} p<0.05$. 
a

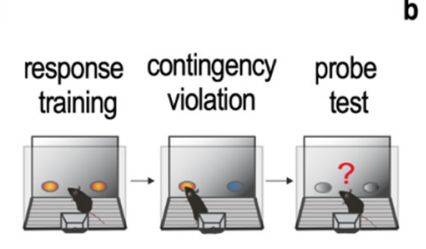

c

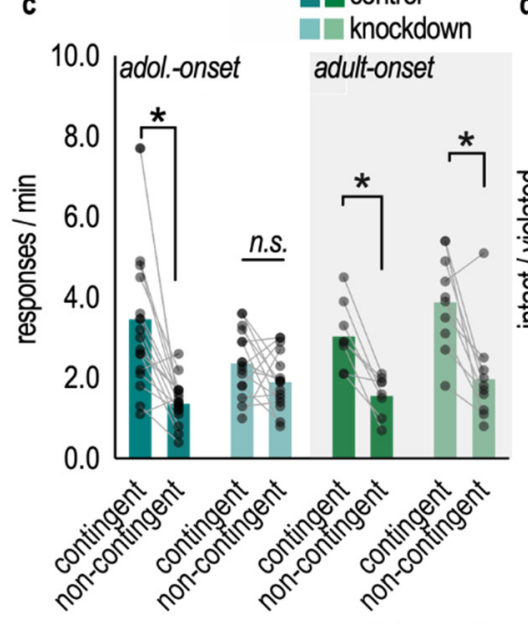

e b adolescent-onset $=$ control adult-onset

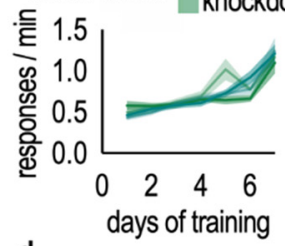

d

6.0 jadol.- adultonset onset

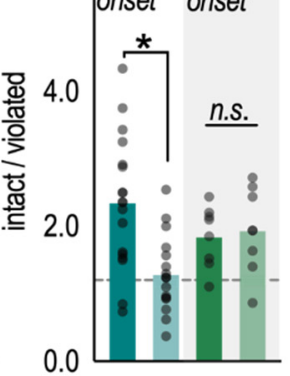

a control knockdown

probe

test
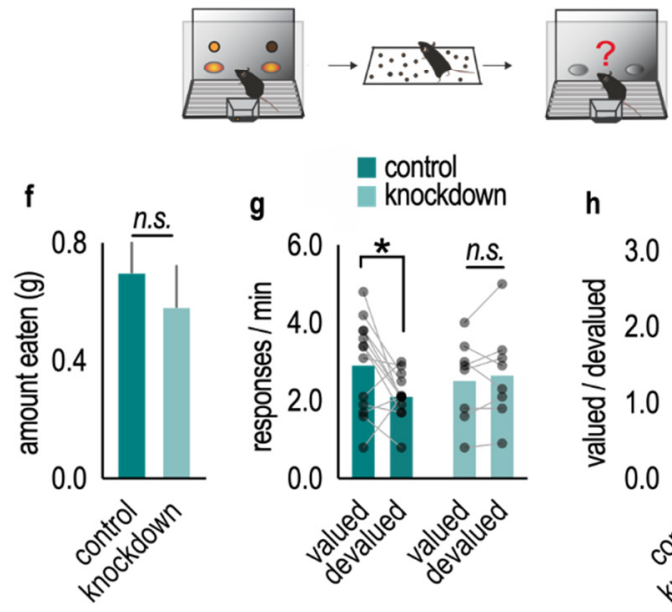

h

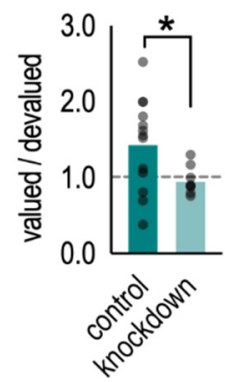

825 Figure 2. Developmentally-selective control of reward-related action by cell adhesion factor

$826 \beta 1$-integrin. a. Schematic. Mice are trained to nose poke at 2 apertures for 2 food reinforcers. Once

827 mice are proficient, the causal relationship between 1 behavior and its outcome is violated.

828 Preferential engagement of the behavior associated with the other, intact contingency is considered

829 flexible action. b. Groups did not differ in response training. There were no systematic preferences 
830 for either flavor of pellet, so response rates for both pellets are collapsed here c. Control mice

831 subsequently inhibited a behavior that was not reinforced and favored a reinforced behavior, but

832 reduction of $\beta 1$-integrins starting in adolescence ablated response preference. Adult-onset loss had

833 no effects. $\mathbf{d}$. The same data can be converted to response ratios (contingent/non-contingent

834 condition). Loss of $\beta 1$-integrins during adolescence, but not adulthood, reduced ratios, indicating

835 that response performance is inflexible. e. Schematic. Mice are trained to nose poke at 2 nose poke

836 apertures for 2 food reinforcers. Once proficient, mice are then allowed to freely consume 1 of the

8372 food reinforcers in a separate environment. In a subsequent probe test, preferential responding

838 for the other food ("valued" condition) is considered goal-directed. f. Groups did not differ in food

839 consumed during the prefeeding session. g. Control mice preferred the aperture associated with

840 the valued food reinforcer, whereas loss of $\beta 1$-integrins ablated this preference. $\mathbf{h}$. Accordingly,

841 preference ratios (valued/devalued) were lower in integrin-deficient mice. Dashed lines at 1 indicate

842 no preference. Bars represent means, error bars represent SEMs, and symbols represent individual

843 mice. ${ }^{*} p<0.05 . n=8-18$ group. 


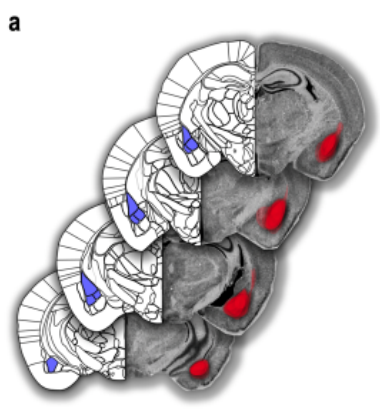

e

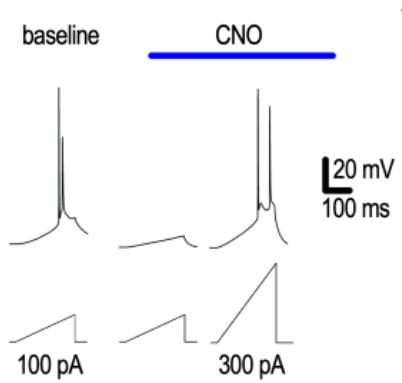

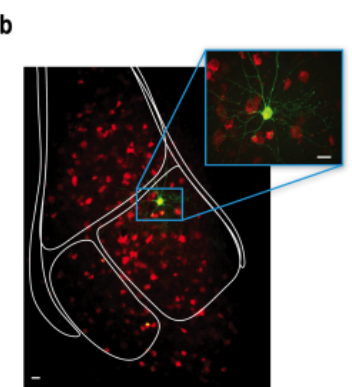
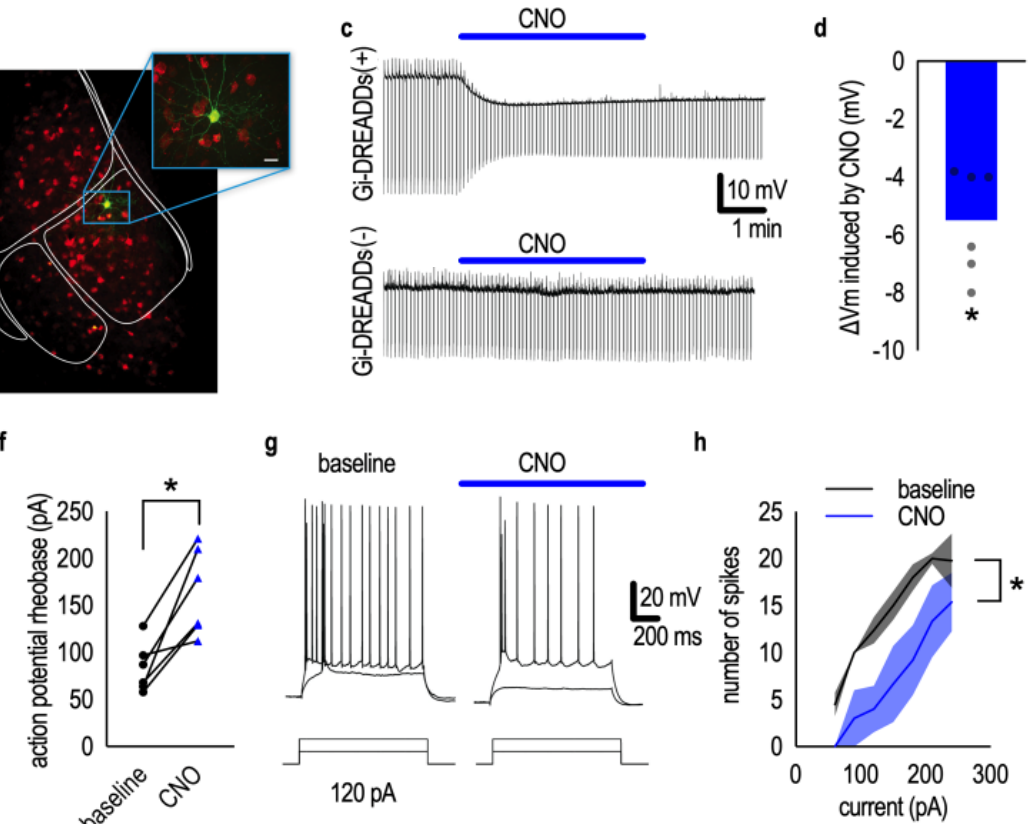

845

846

847

848

849

850

851

852

853

854

855

856

Figure 3. Chemogenetic silencing of PL-projecting BLA neurons. a. To inhibit the activity of projections from the BLA to the $\mathrm{PL}$, mice were infused with viral vectors expressing a Credependent Gi-DREADD into the BLA and a retrograde Cre into the PL. (left) Images from Allen Brain Atlas $^{70}$ (from left: $-1.28 \mathrm{~mm},-1.64 \mathrm{~mm},-2.12 \mathrm{~mm}$, and $-2.72 \mathrm{~mm}$ relative to bregma) depicting the BLA (purple). (right) Overlays of viral vector spread (red) encompassing the BLA on images from Mouse Brain Library ${ }^{69}$. b. Representative image of biocytin-filled (green) BLA neuron expressing Gi-DREADD-mCherry (red); Scale bar=20 $\mu$ m. c. In a Gi-DREADD(+) neuron, bath application of $\mathrm{CNO}(10 \mu \mathrm{M})$ induced fast membrane hyperpolarization and decreased input resistance (upper trace). In a Gi-DREADD(-) neuron, CNO did not induce changes of membrane potential and input resistance (lower trace). d. CNO-induced hyperpolarization in Gi-DREADD(+) neurons. e. Rheobase, the minimal current required to generate action potential, was elevated upon CNO application. f. CNO increased rheobase in Gi-DREADD(+) neurons. g. CNO decreased the number of action potentials induced by 2 current steps. $\mathbf{h}$. CNO decreased action potentials at different current steps. Bars represent means, error bars represent SEMs, and symbols represent individual neurons. ${ }^{*} p<0.05 . n=6$ neurons from 4 mice. 

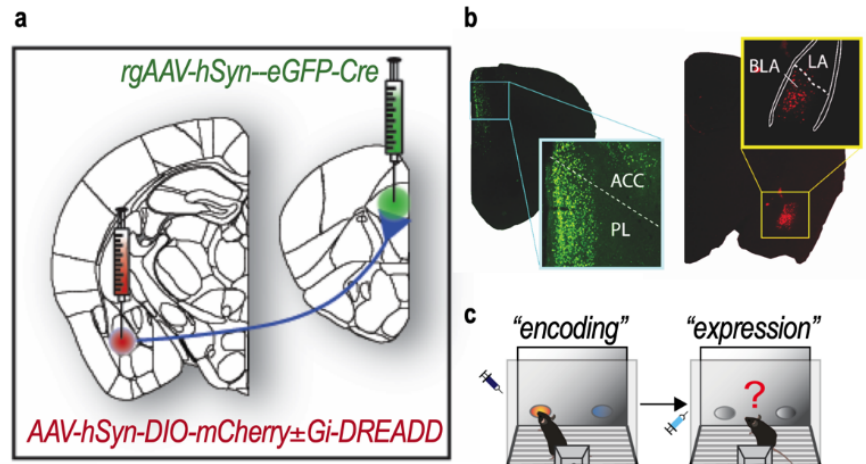

c "encoding" "expression"
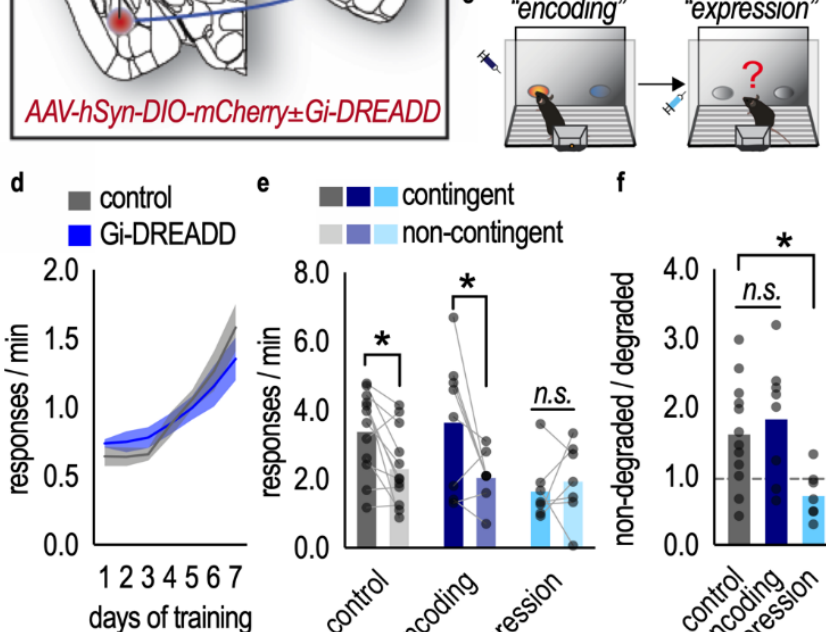

f
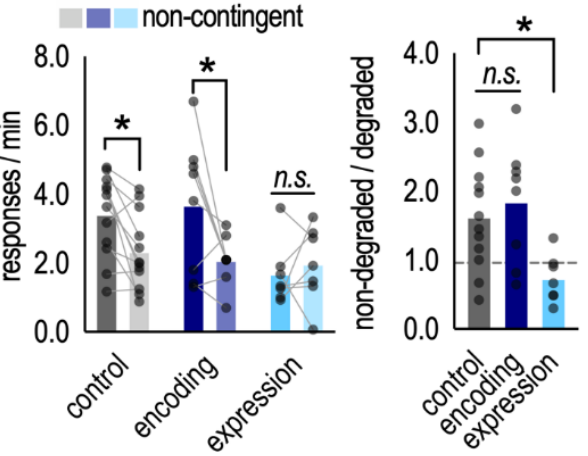

Figure 4. BLA $\rightarrow P L$ connections are necessary for flexible reward-related memory

863 expression. a. Schematic of viral vector approach. Mice were infused with viral vectors expressing

864 a Cre-dependent Gi-DREADD into the BLA and a retrograde Cre into the PL. Control mice received

865 a Cre-dependent fluorophore, but no DREADD, in the BLA. b. Representative infusions in the BLA

866 and PL. c. Mice received $\mathrm{CNO}$ either prior to the session when familiar action-outcome

867 contingencies are being disrupted and new action-outcome memories are being encoded, or prior

868 to the probe test, when mice are expressing recently formed action-outcome memories. d. Groups

869 did not differ in response training. e. BLA $\rightarrow$ PL projection inactivation during the memory "encoding"

870 period had no effect, while BLA $\rightarrow \mathrm{PL}$ inactivation during the "expression" period ablated flexible

871 response shifting. f. The same data are expressed as response preferences. Again, BLA $\rightarrow P L$

872 projection inactivation during the "encoding" period had no effect, while BLA $\rightarrow$ PL projection

873 inactivation during the "expression" period ablated preference. Dashed line at 1 indicates no

874 preference. Bars represent means, error bars represent SEMs, and symbols represent individual

875 mice. ${ }^{*} p<0.05 . \mathrm{ACC}=$ anterior cingulate cortex, LA=lateral amygdala. $n=7-12 /$ group. 

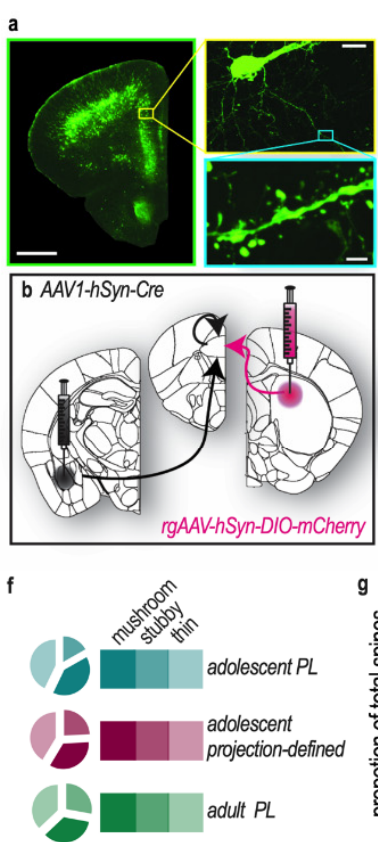

876

877

878

879

880

881

882
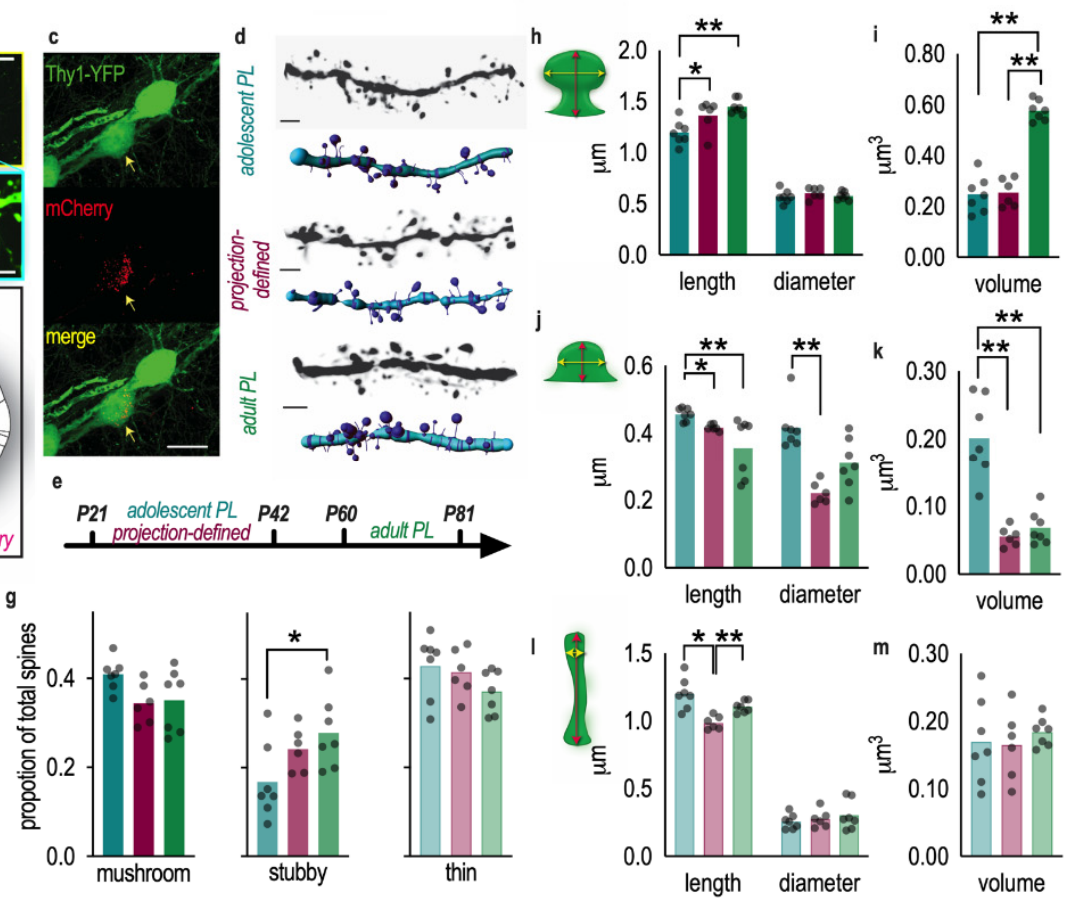

Figure 5. Morphological features of PL neurons receiving input from the BLA and projecting to the DMS. a. Coronal sections from YFP+ mice used to examine dendritic spine architecture on excitatory layer V PL neurons. Scale bar=1 mm (green), $20 \mu \mathrm{m}$ (yellow), $2 \mu \mathrm{m}$ (blue). b. Schematic of viral vector approach. A retrograde viral vector expressing a Cre-dependent fluorophore was infused into the DMS. A transsynaptic anterograde viral vector encoding Cre was infused into the BLA. YFP+mCherry+ PL neurons were imaged. This condition is referred to as "projection-defined." Separate mice received an AAV-mCherry in the PL to transfect a general neuron population not defined by projection pattern. c. Representative PL neuron co-expressing YFP and mCherry (arrowhead). Scale bar=20 $\mu \mathrm{m}$. d. Representative dendrites, with their associated 3D reconstructions. Scale bar $=2 \mu \mathrm{m}$ e. Timeline of experiments portraying time of viral vector delivery (tick mark at the left of text) and euthanasia (tick mark at the right of text), with the three conditions labeled in different colors. f. Pie charts representing the dendritic spine subtype proportions in each group. g. Mature neurons had the highest proportion of stubby-type spines, while projection-defined neurons exhibited an intermediate phenotype. There were no significant differences in the proportions of mature- or thin-type spines. $\boldsymbol{h}$. Projection-defined adolescent PL neurons had longer mushroom-type spines than the general adolescent population, resembling mature morphologies. 
bioRxiv preprint doi: https://doi.org/10.1101/2021.07.12.452062; this version posted July 12, 2021. The copyright holder for this preprint (which

was not certified by peer review) is the author/funder, who has granted bioRxiv a license to display the preprint in perpetuity. It is made available under aCC-BY 4.0 International license.

893 We observed no differences in dendritic spine diameters. i. Mature neurons had mushroom-shaped

894 spines of the largest volume, exceeding both adolescent populations. j. Projection-defined

895 adolescent PL neurons and mature PL neurons had shorter stubby-type spines than the general

896 population of adolescent PL neurons. Projection-defined adolescent PL neurons and mature

897 neurons had smaller stubby-type spine diameters than the general adolescent population. $\mathbf{k}$. Their

898 volumes were also lower. I. Projection-defined adolescent PL neurons had shorter thin-type spines

899 than other groups, and there were no differences in thin spine diameters, or $\mathbf{m}$. thin spine volumes.

900 Bars represent means, and symbols represent individual mice. ${ }^{*} p<0.05,{ }^{* *} p<0.001 . n=6-7 /$ group. 
a

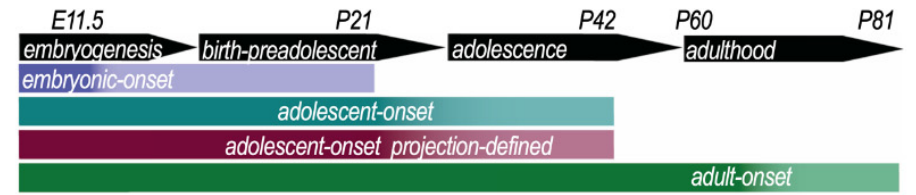

c

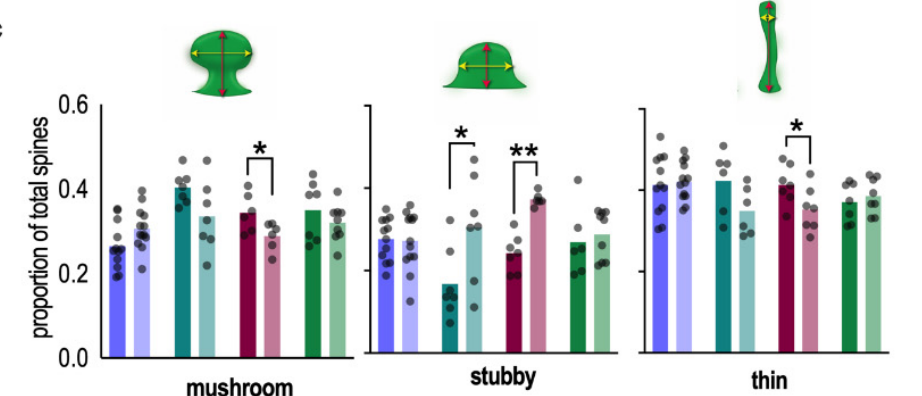

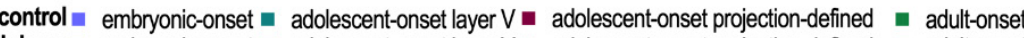
knockdown $=$ embryonic-onset $=$ adolescent-onset layer $\mathrm{V}=$ adolescent-onset projection-defined $=$ adult-onset

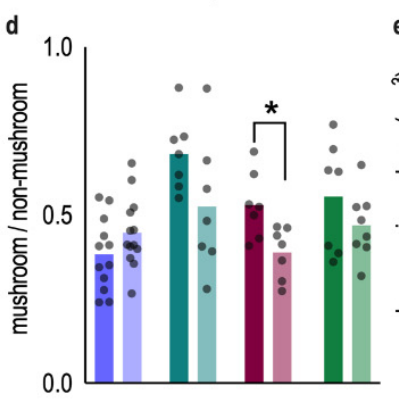

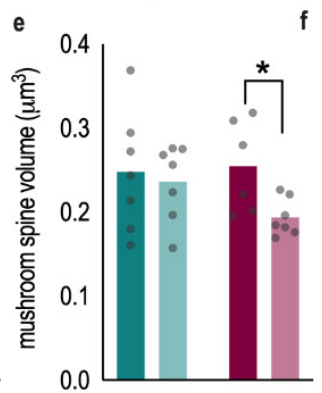

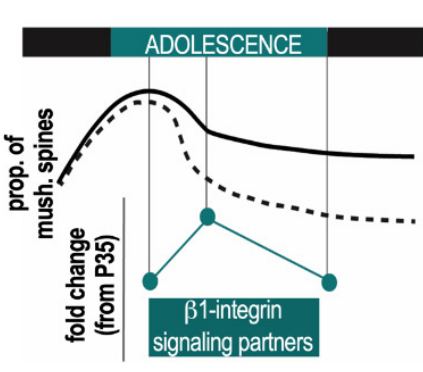

Typical dendritic spine proportions and morphologies

faciliate goal-directed action

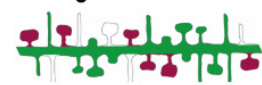

Altered dendritic spine proportions and morphologies in the absence of $\beta 1$-integrins

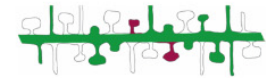

receives projections from $B L A$ $\square$ eliminated during maturation

Figure 6. Cell adhesion control of PL neuronal morphology. a. Timeline. $\beta 1$-integrins were reduced starting in embryogenesis, adolescence (globally or specifically in projection-defined $\mathrm{BLA} \rightarrow \mathrm{PL} \rightarrow \mathrm{DMS}$ neurons), or adulthood. Timing of diminishing $\beta 1$-integrin tone is represented by thinning color gradient. Dendritic spine analysis occurred at P21, P42, or P81 for embryonic-, adolescent-, or adult-onset investigations, respectively. b. Representative dendrites, with their decreased the proportion of mushroom- and thin-type dendritic spines and increased the proportion of stubby-type spines. Embryonic- and adult-onset $\beta 1$-integrin reduction did not affect dendritic spine proportions. d. Adolescent-onset $\beta 1$-integrin loss in projection-defined neurons decreased the proportion of mature mushroom-shaped spines to non-mushroom spines. e. $\beta 1$-integrin tone during adolescence is also required for intact mushroom spine volume on projection-defined neurons. f. Model. Typical dendritic spine densities increase in the PL in the pre-adolescent period, then some dendritic spines are eliminated, and others are stabilized during adolescence. $\beta 1$ - 
bioRxiv preprint doi: https://doi.org/10.1101/2021.07.12.452062; this version posted July 12, 2021. The copyright holder for this preprint (which

was not certified by peer review) is the author/funder, who has granted bioRxiv a license to display the preprint in perpetuity. It is made available under aCC-BY 4.0 International license.

915 integrin signaling partners increase in expression during adolescence ${ }^{12}$. Here, we show that $\beta 1$ -

916 integrin presence stabilizes dendritic spines on PL neurons, including neurons that receive input

917 from the BLA and project to the DMS. Absent this activity, typical proportions and morphologies of

918 mature, mushroom-shaped spines are lost (dashed line), and PL function is compromised in

919 adulthood. Bars represent means. Symbols represent individual mice. ${ }^{*} p<0.05,{ }^{* *} p<0.001$. $n=7$ -

920 13/group. 


\title{
Supplementary Information for
}

Cell adhesion factors during adolescence support amygdalo-cortical connections and flexible action later in life

Henry W. Kietzman, Lauren P. Shapiro, Gracy Trinoskey-Rice, Jidong Guo, Shannon L. Gourley

\author{
Contact: \\ Shannon L. Gourley \\ Yerkes National Primate Research Center \\ Emory University \\ 954 Gatewood Rd. NE \\ Atlanta GA 30329 \\ Email: shannon.l.gourley@emory.edu \\ 404-727-2482
}

This file includes:

Figures S1 to S2 


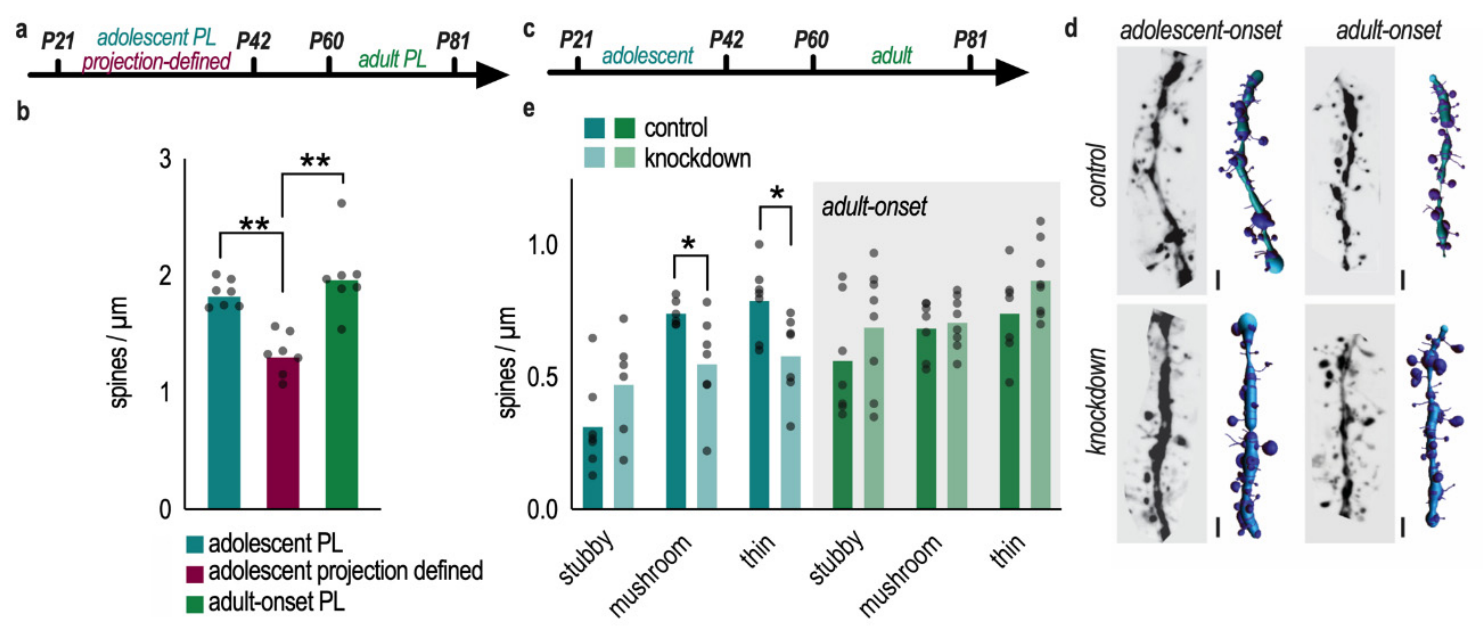

2 Fig. S1. $\beta 1$-integrin loss in adolescence, but not adulthood, decreases dendritic spine

3 density. a. Timeline of experiments portraying time of viral vector delivery and euthanasia. b.

$4 \quad$ Projection-defined PL neurons had lower dendritic spine densities than either mature or adolescent

5 PL neurons that were not defined by projection $\left[F_{(2,18)}=17.10, p<0.0001\right]$. c. Timeline of $\beta 1$-integrin

6 reduction. d. Adolescent-onset $\beta 1$-integrin reduction decreased the density of mushroom-

$7 \quad\left[t_{(11)}=2.469, p=0.0312\right]$ and thin-type $\left[t_{(12)}=2.614, p=0.0210\right]$ dendritic spines. Adult-onset $\beta 1$ -

8 integrin reduction did not affect dendritic spine densities. e. Representative dendrites, with their

9 associated 3D reconstructions. Scale bar $=2 \mu \mathrm{m}$. Bars=means, symbols=individual mice. ${ }^{*} p<0.05$, $10 \quad{ }^{* *} p<0.001$. 
bioRxiv preprint doi: https://doi.org/10.1101/2021.07.12.452062; this version posted July 12, 2021. The copyright holder for this preprint (which

was not certified by peer review) is the author/funder, who has granted bioRxiv a license to display the preprint in perpetuity. It is made available under aCC-BY 4.0 International license.

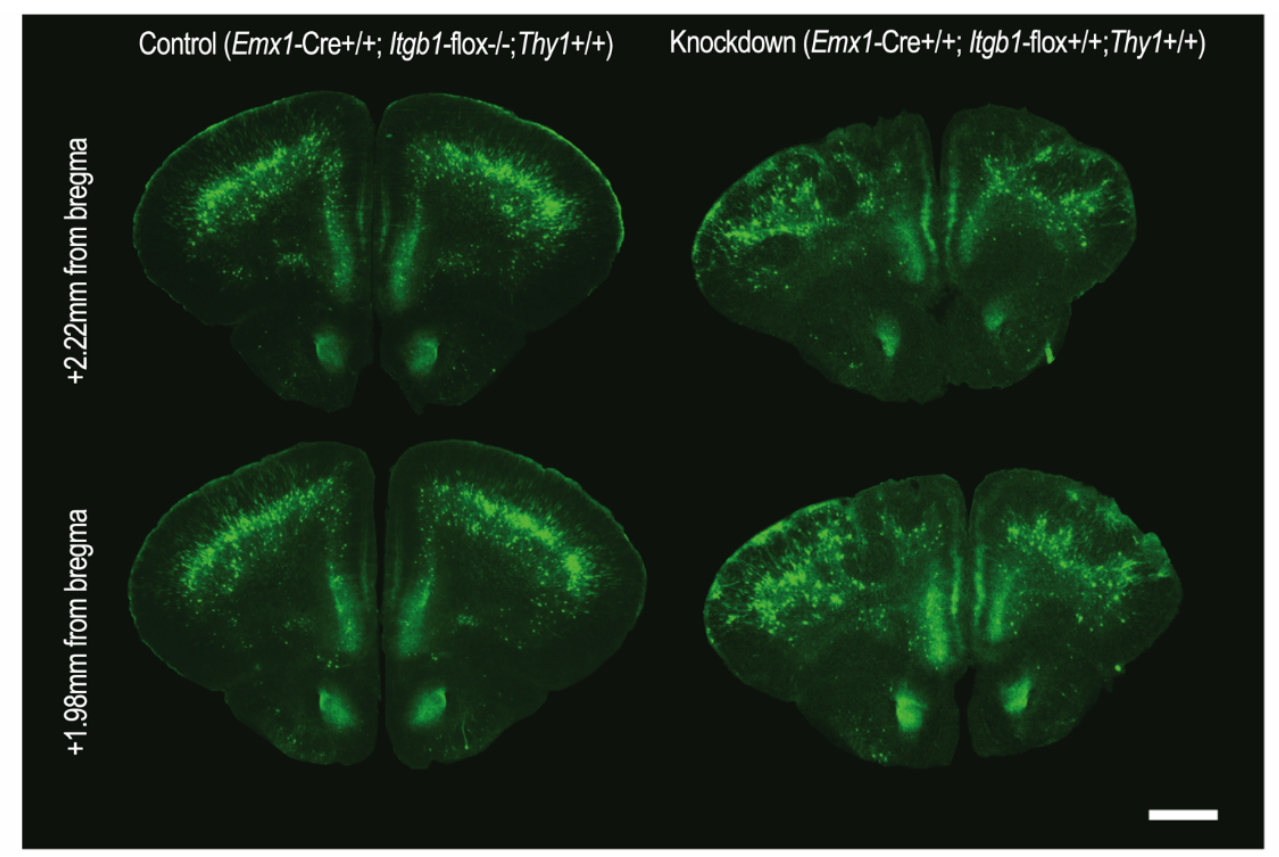

12 Fig. S2. $\beta 1$-integrins are required during embryogenesis for proper cortical layering. (left)

13 Control brain sections at P21 display typical cortical organization, with layer $\mathrm{V}$ neurons expressing

14 YFP. (right) Reduction of Itgb1 starting at embryonic day 11.5 results in disorganized cortical layers

15 at P21. Scale bar=1 $\mathrm{mm}$. 